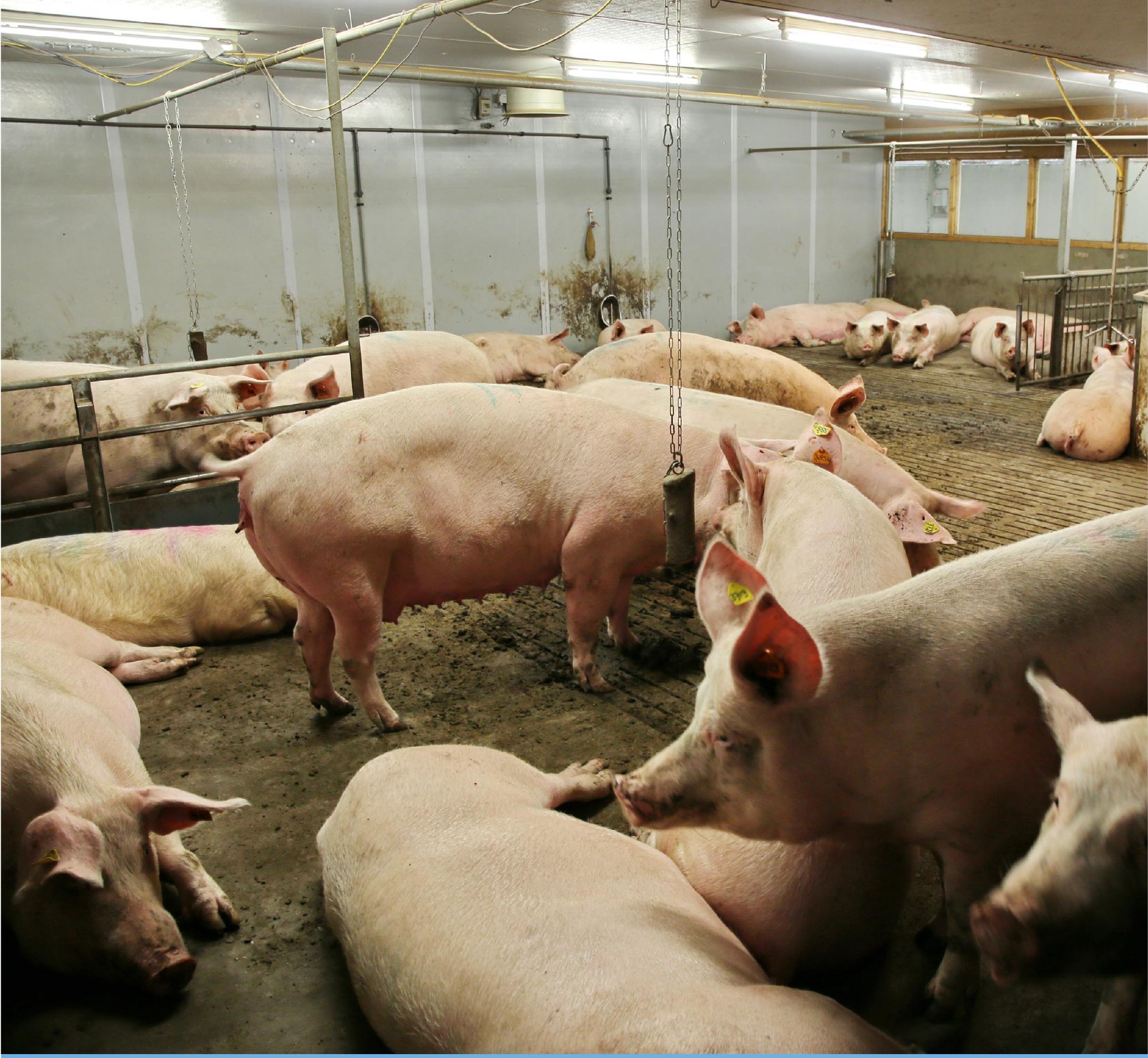

Energy and amino acid requirements of gestating and lactating sows 



\section{Energy and amino acid requirements of gestating and lactating sows}

C.M.C. van der Peet-Schwering, P. Bikker

This research was conducted by Wageningen Livestock Research as part of the Public Private Partnership "Feed4Foodure" (TKI-AF-16123), and funded by Vereniging Diervoederonderzoek Nederland (VDN) and the Ministry of Agriculture, Nature and Food Quality (LNV).

Wageningen Livestock Research

Wageningen, August 2019

Report 1190 
C.M.C. van der Peet-Schwering and P. Bikker, 2019. Energy and amino acid requirement of gestating and lactating sows. Wageningen Livestock Research, Report 1190.

\section{Summary}

In the Netherlands, energy and amino acid recommendations for pigs are published by the Centraal Veevoederbureau (CVB, Central Bureau for Livestock Feeding). The CVB recommendations for sows, have not been updated since 1995. Because the litter size and milk production of the sows have increased in the last 20 years and sows have become heavier and have less backfat, the energy and amino acid recommendations from 1995 had to be updated. The updated energy and amino acid recommendations for parity 1 to 5 gestating and lactating sows are presented in this report.

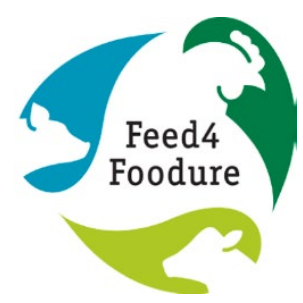

This report can be downloaded for free at https:// doi.org/10.18174/498283 or at www.wur.nl/livestock-research (under Wageningen Livestock Research publications).

(C) 2019 Wageningen Livestock Research

P.O. Box 338, 6700 AH Wageningen, The Netherlands, T +31 (0)317 483953 ,

E info.livestockresearch@wur.nl, www.wur.nl/livestock-research. Wageningen Livestock Research is part of Wageningen University \& Research.

All rights reserved. No part of this publication may be reproduced and/or made public, whether by print, photocopy, microfilm or any other means, without the prior permission of the publisher or author.

Wageningen Livestock Research is NEN-EN-ISO 9001:2015 certified.

All our research commissions are in line with the Terms and Conditions of the Animal Sciences Group. These are filed with the District Court of Zwolle. 


\section{Table of contents}

$\begin{array}{ll}\text { Foreword } & 5\end{array}$

$\begin{array}{ll}\text { Summary } & 7\end{array}$

1

$\begin{array}{ll}\text { Introduction } & 9\end{array}$

$\begin{array}{ll}\text { Assumptions and model description } & 10\end{array}$

2.1 Weight and body composition of the sows at mating and at farrowing 10

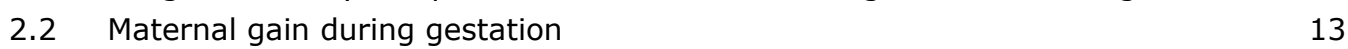

2.3 Development of uterine contents 14

2.4 Development of mammary tissue during gestation $\quad 16$

$\begin{array}{lll}2.5 & \text { Milk production and daily gain of the piglets after birth } & 17\end{array}$

2.5.1 Milk production curves $\quad 17$

2.5.2 Daily gain of the suckling piglets 19

2.5.3 Milk production curves vs daily gain of the piglets 19

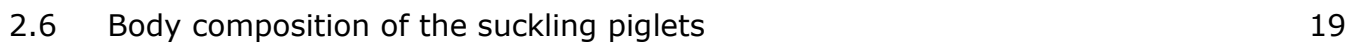

$\begin{array}{lll}2.7 & \text { Milk composition } & 20\end{array}$

$\begin{array}{lll}2.8 & \text { Mobilisation during lactation } & 20\end{array}$

$3 \quad$ Energy metabolism $\quad 22$

3.1 Energy metabolism during gestation $\quad 22$

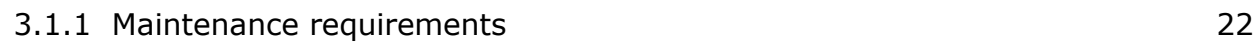

$\begin{array}{ll}3.1 .2 \text { Efficiency of energy utilization } & 22\end{array}$

3.2 Energy metabolism during lactation $\quad 22$

3.2.1 Maintenance requirements lactating sows $\quad 22$

3.2.2 Efficiency of energy utilization for milk production $\quad 22$

3.2.3 Energy requirement of suckling piglets 23

4.1 Amino acid metabolism during gestation $\quad 24$

4.1.1 Maintenance requirements $\quad 24$

4.1.2 Amino acid composition of gestational protein pools $\quad 25$

$\begin{array}{ll}4.1 .3 \text { Efficiency of amino acid utilization } & 27\end{array}$

4.2 Amino acid metabolism during lactation $\quad 28$

4.2.1 Maintenance requirements $\quad 28$

4.2.2 Amino acid composition in milk $\quad 29$

$\begin{array}{ll}4.2 .3 \text { Efficiency of amino acid utilization } & 29\end{array}$

$5 \quad$ Energy and amino acid requirements $\quad 32$

5.1 Gestating sows $\quad 32$

5.1.1 Energy requirement $\quad 32$

$\begin{array}{ll}5.1 .2 \text { Lysine requirement } & 33\end{array}$

5.1.3 Ratio of essential amino acids to lysine 34

5.1.4 Influence of sow characteristics on requirements 34

$\begin{array}{ll}5.1 .5 & \text { Updated recommendations }\end{array}$

$\begin{array}{lll}5.2 & \text { Lactating sows } & 36\end{array}$

5.2.1 Energy requirement 36

$\begin{array}{ll}5.2 .2 \text { Lysine requirement } & 37\end{array}$

5.2.3 Ratio of essential amino acids to lysine 38

$\begin{array}{ll}\text { 5.2.4 Updated recommendations } & 39\end{array}$ 
References

43

Appendix 1 Development in BW and body composition of sows 


\section{Foreword}

The research "Energy and amino acid requirements of gestating and lactating sows" was conducted by Wageningen Livestock Research as part of the Public Private Partnership "Feed4Foodure", and was funded by Vereniging Diervoederonderzoek Nederland (VDN) and the Ministry of Agriculture, Nature and Food Quality (LNV). The authors thank VDN and LNV for their support, and the members of the Cluster "Swine" of VDN for their valuable and inspiring contribution to the research.

The authors:

Carola van der Peet-Schwering and Paul Bikker 


\section{Summary}

Knowledge about the energy and amino acid $(A A)$ requirements is essential in formulating diets for gestating and lactating sows. During gestation, sufficient body reserves must be built to compensate for the nutritional deficit that may occur in the following lactation. However, these reserves should not be excessive as fat sows may have increased farrowing problems, locomotion disorders and impaired feed intake after weaning. During lactation, nutrient requirements are based on maximizing milk production and daily gain of the piglets and minimizing reproductive problems of sows after weaning. Everts et al. $(1994 ; 1995)$ proposed recommendations for energy and amino acid (lysine, methionine+cystine, threonine and tryptophan) supply for gestating and lactating sows for the CVB, based on a factorial approach. The CVB recommendations, however, have not been updated since 1995. Because the litter size and milk production of the sows has increased in the last 20 years and sows have become heavier and have less backfat, the energy and amino acid recommendations had to be updated.

The present report incorporates new data and insights published after 1995, using a similar approach like Everts et al. $(1994 ; 1995)$. The factorial estimation of energy and all essential AA requirements of sows is based on the requirements for maintenance, the retention of protein/AA and lipid in the body, in the mammary gland and in products of conception (foetuses, placenta and fluids), the excretion of protein/AA and lipid in milk, the mobilisation of body protein/AA and lipid and the efficiency with which protein, lipid and standardized ileal digestible (SID) AA are used for these processes. The essential AA requirements are based on standardized digestibility of AA in feed materials, meaning that basal endogenous losses from the digestive tract are included in the requirement for maintenance. The basal endogenous losses are influenced by feeding level of the sows. Relevant deviations from methods and results in Everts et al. $(1994 ; 1995)$ have been discussed in the report. The updated energy and SID essential AA recommendations for parity 1 to 5 gestating and lactating sows are presented in chapter 5 of this report. The recommendations are presented per week and per month of gestation and per week op lactation. 


\section{Introduction}

This report aims to provide recommendations for the energy and amino acids requirements for gestating and lactating sows. Everts et al. $(1994 ; 1995)$ proposed recommendations for energy and amino acid supply for gestating and lactating sows for the CVB, based on a factorial approach, which have been used since then by the Dutch feed industry. The present report incorporates new data and insights published thereafter, using a similar approach. The factorial estimation of energy and amino acids requirements of sows is based on the requirements for maintenance, the retention of protein/amino acids and lipid in the body and in products of conception, the excretion of protein/amino acids and lipid in milk and the efficiency with which protein, lipid and standardized ileal digestible (SID) amino acids are used for these processes. This method was first introduced by ARC (1967) and subsequently developed and used by Everts et al. (1994; 1995); Dourmad et al. (1999), Dourmad et al. (2008) and NRC (2012).

During gestation, sufficient body reserves must be built to compensate for the nutritional deficit that may occur in the following lactation (Dourmad et al., 2008). However, these reserves should not be excessive as fat sows may have increased farrowing problems, locomotion disorders and impaired feed intake after weaning (Dourmad et al., 2008). Conversely, sows that become too thin due to inadequate energy and nutrient intake experience reduced time in the breeding herd (Knauer et al., 2010) and increased culling rates (Hughes et al., 2010). During lactation, nutrient requirements are based on maximizing milk production and daily gain of the piglets and minimizing reproductive problems of sows after weaning (Dourmad et al., 2008). Several researchers have demonstrated that excessive lactation weight loss resulting from low voluntary nutrient intake relative to milk output lengthens the post-weaning interval to oestrus and increases the incidence of anoestrous sows (Koketsu et al., 1996a; Yoder et al., 2013).

In this report we will subsequently address the development in weight and body composition of the sows, conceptus (foetus, placenta and fluid), udder, body composition of the piglets and milk production (chapter 2), inevitable losses and maintenance requirements of energy (chapter 3 ) and amino acids (Chapter 4), energy (chapter 3 ) and amino acid (chapter 4 ) requirements of sows in gestation and lactation based on protein/amino acids and lipid retention during gestation and milk production and tissue mobilisation in lactation. In chapter 5 , the energy and amino acid requirements of gestating and lactating sows are presented. 


\section{Assumptions and model description}

In this chapter the development in body weight (BW) and body composition of the sows, conceptus (foetus, placenta and fluid), mammary tissue, body composition of the piglets and milk production will be described. These data are necessary to estimate the requirements of energy and amino acids of gestating and lactating sows. Maternal BW is BW of the sow without conceptus (foetus, placenta and fluids).

\subsection{Weight and body composition of the sows at mating and at farrowing}

Reproductive sows continue to grow during a number of parities. CVB (2016) assumed a maternal gain, excluding uterine contents, of $55 \mathrm{~kg}$ in the $1^{\text {st }}$ gestation, decreasing to $30 \mathrm{~kg}$ in the $6^{\text {th }}$ gestation (Table 1). Part of this maternal gain is required to replenish mobilised tissue (protein and fat) in the previous lactation, the remainder can be regarded as real gain of the sows to reach mature body weight (BW). We assumed this maternal gain, derived from CVB (2016), as representative for a sow herd and used these data for the calculation of energy and amino acid requirements.

Table 1 Maternal weight development (excluding uterine contents: foetus, placenta and fluids) of sows during gestation and lactation (CVB, 2016; Bikker and Blok, 2017).

\begin{tabular}{|c|c|c|c|c|c|c|}
\hline Parity & 1 & 2 & 3 & 4 & 5 & 6 \\
\hline \multicolumn{7}{|l|}{ Mating } \\
\hline Maternal body weight, kg & 140 & 165 & 185 & 205 & 220 & 235 \\
\hline Backfat, $\mathrm{mm}$ & 13 & 12 & 13 & 13 & 13 & 13 \\
\hline \multicolumn{7}{|l|}{ Gestation } \\
\hline Maternal gain, kg & 55 & 50 & 45 & 40 & 35 & 30 \\
\hline \multicolumn{7}{|l|}{ Farrowing } \\
\hline Maternal body weight, kg & 195 & 215 & 230 & 245 & 255 & 265 \\
\hline Backfat, mm & 17 & 17 & 17 & 17 & 17 & 17 \\
\hline
\end{tabular}

${ }^{1}$ Including a weight loss of $7.5 \mathrm{~kg}$ and $0.75 \mathrm{~mm}$ backfat after weaning, including involution of the mammary gland

From the maternal BW and backfat thickness at mating and at farrowing, the protein and lipid content at mating and at farrowing can be estimated. Several equations to estimate protein and lipid content are used in literature. They are based on the following data:

1. Everts et al. (1994), based on Everts and Dekker (1995a and 1995b). Forty-eight gilts and sows (Large White $x$ Dutch Landrace sows) were chemically analysed at first mating $(n=11)$, end of first gestation $(n=14)$ and after weaning of the 3rd lactation $(n=23)$.

2. InraPorc (Dourmad et al., 2008) and NRC (2012), based on Dourmad et al. (1997). One hundred and eighty nine Large White sows (108 primiparous and 81 mulitparous sows) were dissected and among them, 23 primiparous sows were chemically analysed after parturition $(n=7)$ and after weaning ( $n=16)$. The equations were calculated using the double regression technique, empty body weight $(E B W, \mathrm{~kg})$ and backfat depth $(\mathrm{P} 2, \mathrm{~mm})$ being used as predictors of the chemical composition.

3. Gill (2006). Eighty-nine gilts (71 Large White $x$ Landrace FF1 hybrid gilts and 18 Landrace $x$ (Meishan $x$ Large White) hybrid gilts) were chemically analysed at $50 \mathrm{~kg}(\mathrm{n}=10), 90 \mathrm{~kg}(\mathrm{n}=10)$, mating $(n=20)$, parturition $(n=9)$ and weaning $(n=40)$. 
4. Miller (2017). Twenty-nine gilts and sows (Yorkshire) were chemically analysed at first mating $(n=8)$ and after weaning of the 3rd lactation $(n=21)$.

The following equations to estimate the protein and lipid content in sows were derived in the respective publications:

Protein:

1. Protein $(\mathrm{kg})=1.90+0.1711 \times$ maternal BW $-0.3113 \times$ backfat $(P 2, \mathrm{~mm})$ (Everts et al., 1994$)$

2. Protein $(\mathrm{kg})=2.28+0.178 \times 0.96 \times$ maternal BW $-0.333 \times 1.22 \times$ backfat $(\mathrm{P} 2, \mathrm{~mm})$ (Dourmad et al., 1997). Dourmad et al. (1997) measured P2 backfat ultrasonically before slaughter and with an endoscope after slaughter. Ultrasonic backfat was $1.22 \times$ backfat after slaughter. Therefore we included a factor 1.22 in the equation.

3. Protein $(\mathrm{kg})=0.2 \times(0.96 \times$ maternal BW - lipid mass $)(P 2, \mathrm{~mm})(\mathrm{Gill}, 2006)$

4. Protein $(\mathrm{kg})=4.07+0.17 \times 0.96 \times$ maternal $B W-0.23 \times$ backfat $(P 2, \mathrm{~mm})($ Miller, 2017$)$

Lipid:

1. Lipid $(\mathrm{kg})=-11,58+0.1207 \times$ maternal BW $+1.904 \times$ backfat (Everts et al., 1994)

2. Lipid $(\mathrm{kg})=-26.4+0.221 \times 0.96 \times$ maternal BW $+1.331 \times 1.22 \times$ backfat (Dourmad et al., 1997)

3. Lipid $(\mathrm{kg})=-8.14+0.167 \times$ maternal BW $+0.883 \times$ backfat (Gill, 2006)

4. Lipid $(\mathrm{kg})=-20.72+0.27 \times 0.96 \times$ maternal $B W+0.77 \times$ backfat (Miller, 2017)

In Table 2, the protein and lipid content at mating and farrowing for the sows as described in Table 1 are presented, based on the equations of Everts et al. (1994), Dourmad et al. (1997), Gill (2006) and Miller (2017).

Table 2 Protein and lipid content (excluding foetus, placenta and fluids) at mating and farrowing in sows defined in Table 1, as calculated with equations developed by Everts et al. (1994), Dourmad et al. (1997) (modified as described above), Gill (2006) and Miller (2017).

\begin{tabular}{|c|c|c|c|c|c|}
\hline Parity & 1 & 2 & 3 & 4 & 5 \\
\hline \multicolumn{6}{|l|}{ Everts et al. (1994) } \\
\hline \multicolumn{6}{|l|}{ Mating } \\
\hline Protein mass, $\mathrm{kg}$ & 21.8 & 26.4 & 29.5 & 32.9 & 35.5 \\
\hline Lipid mass, kg & 27.6 & 28.2 & 32.2 & 34.2 & 35.8 \\
\hline \multicolumn{6}{|l|}{ Farrowing } \\
\hline Protein mass, $\mathrm{kg}$ & 30.0 & 33.4 & 36.0 & 38.5 & 40.2 \\
\hline Lipid mass, kg & 40.8 & 42.9 & 44.4 & 45.9 & 47.0 \\
\hline \multicolumn{6}{|c|}{ Dourmad et al. (1997) } \\
\hline \multicolumn{6}{|c|}{ Mating } \\
\hline Protein mass, kg & 20.9 & 25.6 & 28.6 & 32.0 & 34.6 \\
\hline Lipid mass, kg & 24.4 & 28.1 & 34.0 & 38.2 & 41.4 \\
\hline \multicolumn{6}{|l|}{ Farrowing } \\
\hline Protein mass, kg & 28.7 & 32.1 & 34.7 & 37.2 & 39.0 \\
\hline Lipid mass, kg & 42.6 & 46.8 & 50.0 & 53.2 & 55.3 \\
\hline \multicolumn{6}{|l|}{ Gill (2006) } \\
\hline \multicolumn{6}{|l|}{ Mating } \\
\hline Protein mass, kg & 21.5 & 25.7 & 28.7 & 31.9 & 34.2 \\
\hline Lipid mass, kg & 26.7 & 30.0 & 34.2 & 37.6 & 40.1 \\
\hline \multicolumn{6}{|l|}{ Farrowing } \\
\hline Protein mass, kg & 29.6 & 32.7 & 35.1 & 37.5 & 39.1 \\
\hline Lipid mass, kg & 39.4 & 42.8 & 45.3 & 47.8 & 49.5 \\
\hline \multicolumn{6}{|l|}{ Miller (2017) } \\
\hline \multicolumn{6}{|l|}{ Mating } \\
\hline Protein mass, kg & 23.9 & 28.2 & 31.3 & 34.5 & 37.0 \\
\hline Lipid mass, $\mathrm{kg}$ & 25.6 & 31.3 & 37.2 & 42.4 & 46.3 \\
\hline \multicolumn{6}{|l|}{ Farrowing } \\
\hline Protein mass, kg & 32.0 & 35.3 & 37.7 & 40.1 & 41.8 \\
\hline Lipid mass, kg & 42.9 & 48.1 & 52.0 & 55.9 & 58.5 \\
\hline
\end{tabular}


The predicted protein contents at mating and at farrowing with the four equations are quite similar. The predicted lipid content, however, differs between the equations.

In Everts and Dekker (1995b), the sows contained 19.1\% lipid per kg BW after weaning from the $3^{\text {rd }}$ lactation. In Dourmad et al. (1997), the $1^{\text {st }}$ parity sows contained $21.6 \%$ lipid per $\mathrm{kg}$ BW. In the study of Miller (2017), the gilts at mating and the $3^{\text {rd }}$ parity sows after weaning contained 25.6 and $23.5 \%$ lipid per kg of empty BW, respectively. In Gill (2006), Large White gilts contained 21.4, 21.8, 19.3\% lipid per $\mathrm{kg}$ of BW at mating, farrowing and after weaning, respectively. The Meishan gilts contained $26.5,25.7$ and $23.4 \%$ lipid per $\mathrm{kg}$ of BW, respectively.

In Figure 1, the predicted lipid content is presented in relation to BW at a fixed backfat thickness (13 and $17 \mathrm{~mm}$ ) and in relation to backfat thickness at a fixed BW (200 and $280 \mathrm{~kg}$ ).

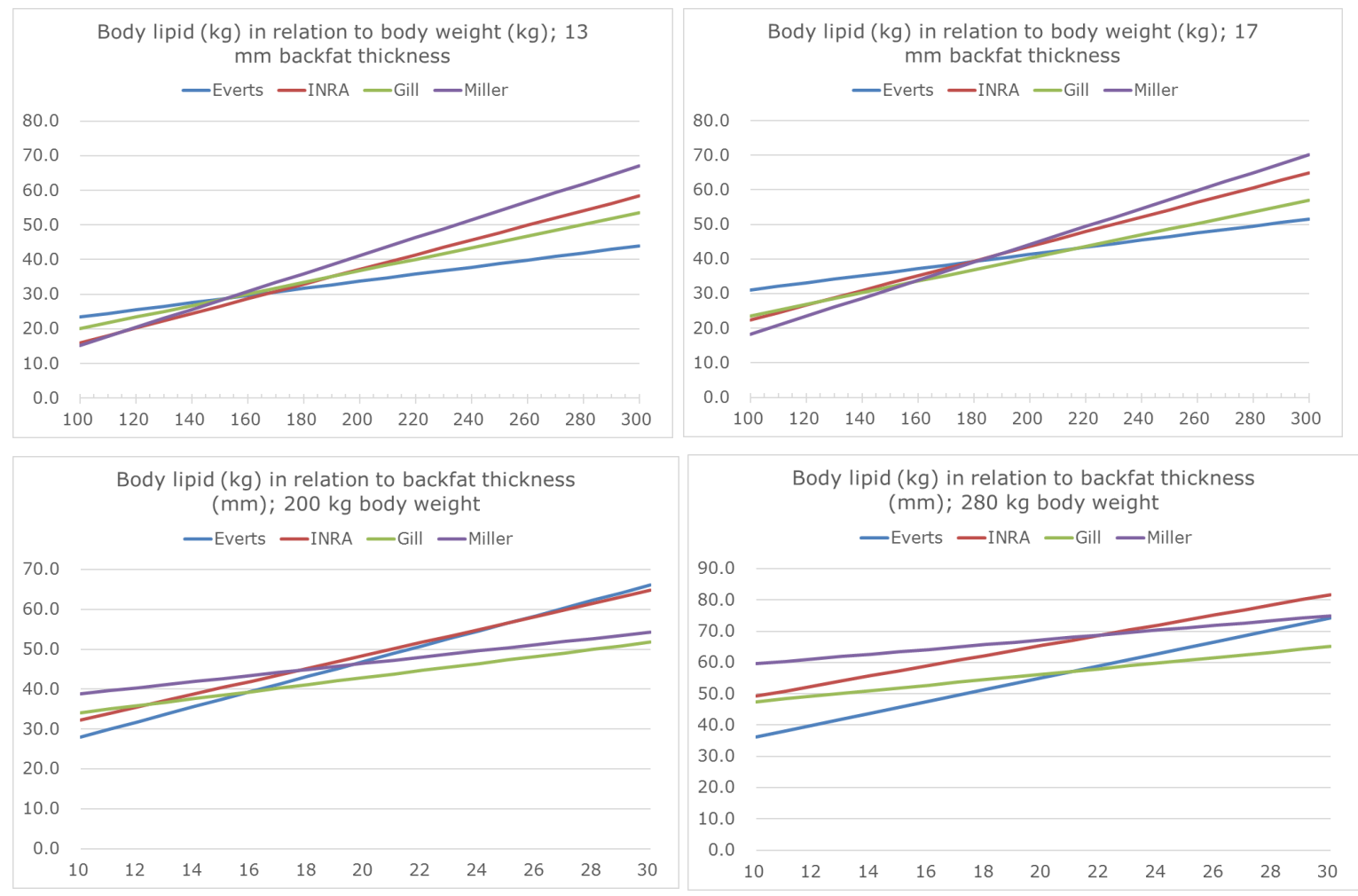

Figure 1 Body lipid $(\mathrm{kg})$ in relation to body weight and to backfat thickness.

The equations of Dourmad et al. (1997) are based on a high number of sows and we judge that the development in protein and lipid content in relation to BW and backfat thickenss still seems to apply to the current sows. Therefore, we used the equations of Dourmad et al. (1997) to predict the content of protein and fat in sows at mating and at farrowing.

The effect of BW on body lipid is smaller in Everts et al. (1994) than in the other studies (Figure 1). At a fixed backfat thickness, the percentage of lipid in the body is decreasing with increasing BW in Everts et al. (1994), while this is not or to a lesser extent observed in the other studies. A decreasing percentage of lipid at a fixed backfat thickenss seems not logical and therefore we decided not to use the equations from Everts et al. (1994).

The sows in Miller (2017) clearly contained more lipid than the sows in the other studies (Table 2). Besides the number of chemically analysed sows was relatively small. Therefore, we decided not to use the equations from Miller (2017).

Gill (2006) used 50 and $90 \mathrm{~kg}$ pigs containing less lipid than gilts at mating and farrowing and they used Meishan hybrid gilts containing more lipid than Large White $\mathrm{x}$ Landrace hybrid gilts to predict the protein and lipid content. Therefore, we decided not to use the equations from Gill (2006).

In Appendix 1, the maternal weight development and the development in maternal protein and lipid mass of the sows defined in Table 1, based on the (modified) equations of Dourmad et al. (1997), is described. This information is used as input in the model. Also, the litter size and birth weight of the piglets, as used in the model, is presented in Appendix 1. 


\subsection{Maternal gain during gestation}

As mentioned before, maternal gain of the sow (as presented in Table 1 and 2) excludes gain of the conceptus (foetus, placenta and fluids) but includes gain of the mammary tissues. As mammary tissue is mainly being developed in late gestation (Noblet et al., 1985; Ji et al., 2006), maternal gain is divided in gain of the mammary tissue and remaining maternal gain as in Everts et al. (1994). The development of mammary tissue is described in chapter 2.4 .

Everts et al. (1994) assumed a constant remaining maternal daily gain and daily protein and lipid deposition during gestation because of lack of data about the development of maternal gain during gestation. Since then, more studies were published. Dourmad et al. (1996), observed a significant and transitory increase in $\mathrm{N}$ retention around day 32 of gestation (Figure 2). These authors concluded that the increase of $\mathrm{N}$ retention around $\mathrm{d} 32$ of pregnancy was related to an increase of $\mathrm{N}$ retention in maternal tissues (because retention in products of conception was still negligible), whereas the increase in $\mathrm{N}$ retention in late pregnancy was mainly related to the development of the conceptus and the udder. During early gestation, nutrients are predominately used for maternal gain, restoration of body reserves, and maintenance, whereas the nutrient demand for foetal growth is still very low (Dourmad et al., 1996). Therefore, Dourmad et al. (1996) and Noblet et al. (1990) suggested that from early to mid-gestation would be the ideal time for restoration of maternal tissues mobilized in a previous lactation, and maternal gain required to reach physical maturity.

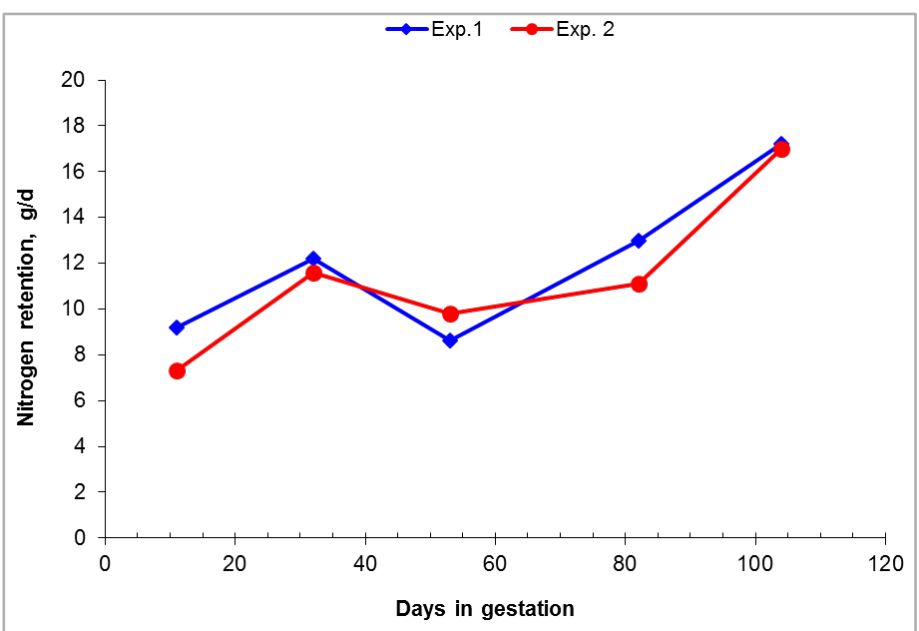

Figure 2 Effect of stage of pregnancy on nitrogen retention in multiparous sows (Dourmad et al., 1996).

Based on Dourmad et al. (1996), NRC (2012) distinguished a time dependent and energy intake dependent maternal body protein deposition. Time-dependent maternal body protein deposition occurs during early gestation when foetal growth is low, and cannot be associated with energy intake or reproductive tissues. Time-dependent maternal body protein deposition is highest around day 32 of gestation and decreases to zero at day 56 (NRC, 2012).

Recently, Miller et al. $(2016,2017)$ determined whole-body and maternal protein deposition in gilts and in parity 2 and 3 sows at 2 different feeding levels during gestation (Figure 3). In parity 2 and 3 sows, maternal protein deposition was not influenced by day of gestation, meaning a constant maternal protein deposition from d 36 to 106 as assumed in Everts et al. (1994). In gilts, however, maternal protein deposition was higher in early gestation (day 38 ) than in mid and late gestation. Miller et al. (2016) suggested that the higher maternal protein deposition during early gestation may be attributed to time-dependent maternal protein deposition. From day 66 to 108 of gestation, maternal protein deposition slightly decreased in the gilts. This slight decrease observed in gilts was suggested to be due to physiological competition for energy and nutrients between maternal and foetal tissues that was independent of nutrient supply (Miller et al., 2016). Due to the greater requirement for maternal growth in first parity sows, competition for nutrients is likely more pronounced (Miller et al., 2016). 

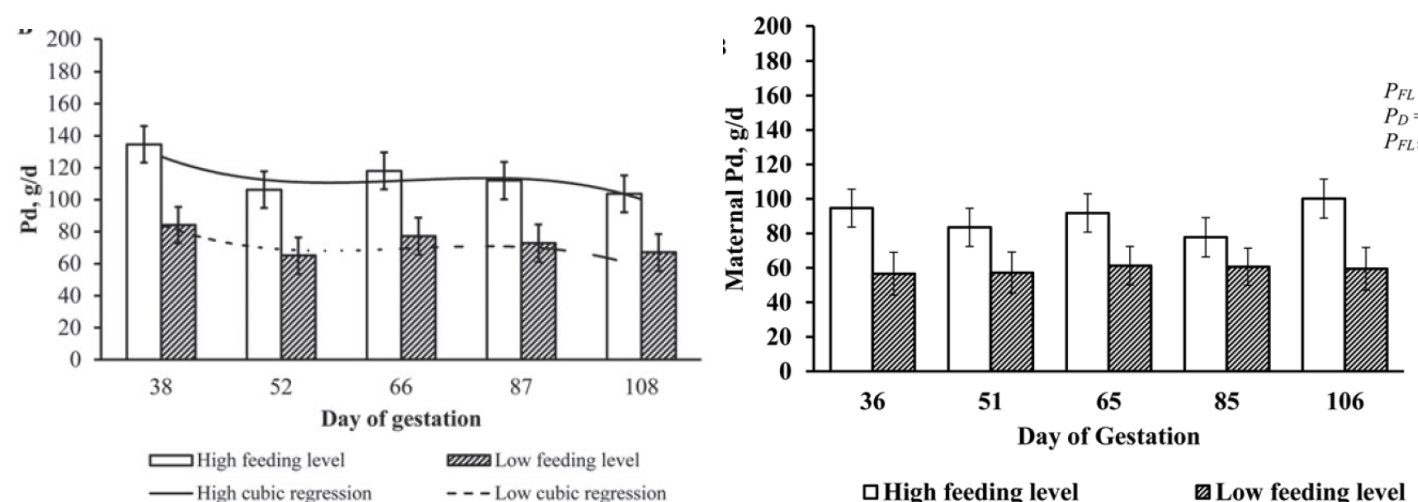

Figure 3 Maternal protein deposition between d 32 and 112 of gestation in gilts (left Figure; Miller et al., 2016) and sows (parity-2 and -3 combined; right Figure; Miller et al., 2017) at high or low feeding level. $P_{F L}, P_{D}$, and $P_{F L \times D}$ represent $P$-values for feeding level, day of gestation, and the interaction between feeding level and day of gestation, respectively. Maternal protein deposition was calculated as the difference between whole-body protein deposition and assumed pregnancy-associated (foetus, mammary gland, uterus, and placenta and fluids) protein deposition for each $N$ balance period.

In conclusion, some studies suggest a transient increase in maternal protein deposition in early gestation at constant daily energy allowance, which might be hormonally regulated, e.g. by an increase in oestrogen level (Dourmad et al., 1999). This was however, not confirmed in other studies (Theil et al., 2002a; Miller et al., 2017). Therefore, we did not include time-dependent maternal protein deposition in the model. Nonetheless, early to mid-gestation may be the best period for restoration of body condition, as supported by the work of Hoving et al. (2011). This study showed that an increased feeding level from day 3 to 32 of the second and third gestation ( $3.25 \mathrm{vs} 2.5 \mathrm{~kg}$ ) improved sow BW gain and increased litter size by 2 piglets. From day 32 until farrowing all sows were fed at the same level. The increased feeding level increased BW gain and backfat during early pregnancy, indicating a greater compensation of the lactational losses compared with the standard feeding level.

Because of the potential benefits of restoration of previous losses of body protein and lipid in early gestation, when growth of uterine contents is low, we included this option in the model. For this purpose, maternal gain (protein and lipid) was divided in restoration of losses in previous lactation and real growth to reach mature body weight. Real growth is assumed constant during gestation.

Restoration of previous losses (protein and lipid) is either constant during gestation (default) or a user-defined portion is additionally recovered in early gestation (the remaining portion is recovered during the whole gestation). Growth of the mammary gland is always included according to equations in chapter 2.4 .

For example in a parity 2 sow, the maternal gain during gestation is $50 \mathrm{~kg}$ of which $20 \mathrm{~kg}$ is real maternal gain, $4.8 \mathrm{~kg}$ is gain of mammary tissue and $25.2 \mathrm{~kg}$ is recovery of maternal loss during lactation:

1. constant maternal daily gain: maternal daily gain $=(20+25.2 \mathrm{~kg}) / 115$ days $=393 \mathrm{~g} / \mathrm{d}$

2. complete or partial recovery of maternal loss in early gestation and constant real maternal gain:

a. real maternal gain $=20 \mathrm{~kg} / 115$ days $=174 \mathrm{~g} / \mathrm{d}$ from day 1 to day 115

b. $100 \%$ recovery in 42 days: $25.2 \mathrm{~kg} / 42$ days $=600 \mathrm{~g} / \mathrm{d}$ in the first 42 days of gestation and $0 \mathrm{~g} / \mathrm{d}$ from day 42 to day 115

c. $50 \%$ extra recovery in 42 days: $(25.2 \mathrm{~kg} \times 0.5 / 42$ days $)+(25.2 \mathrm{~kg} \times 0.5 / 115$ days $)=300$ $+110=410 \mathrm{~g} / \mathrm{d}$ in the first 42 days of gestation and $110 \mathrm{~g} / \mathrm{d}$ from day 42 to day 115

The nutrient requirements (energy and amino acids) are calculated according to the selected profile of recovery of maternal losses.

\subsection{Development of uterine contents}

The development in weight, energy retention and protein retention of foetuses, placenta and fluids during gestation are largely based on Noblet et al. (1985). The development in weight and composition is based on day of gestation (d), litter size (LS) and energy (ME) intake. These equations 
were used by Everts et al. (1994), Dourmad et al. (2008) and NRC (2012) but also by Feyera et al. (2017) and Dourmad et al. (2018) as there are no recent data to predict the development of the uterus contents. In addition, predictions are generally corrected for the actual litter weight at birth as in Bikker and Blok (2017).

Weight of the foetuses, placenta and fluids:

The weight of the foetuses, placenta and fluids during gestation are described with the next equations:

Ln litter weight $(g)=8.72962-4.07466 * \exp (-0.03318 *(d-45))+0.00154 * 30 * d+0.06774 *$ LS

In this equation, the factor "30" represents the mean ME intake (ME in MJ/d) in gestation. Since birth weight of piglets is relatively independent of feeding level, provided that sows receive an adequate amount of feed, a fixed value of 30 was used. The result of this equation is multiplied by the ratio between actual litter birth weight (litter size $\mathrm{x}$ individual birth weight) and predicted litter weight at birth (the value on $d=115$ ) to correct for actual birth weight.

Ln weight placenta $(g)=7.02746-0.95164 * \exp (-0.06879 *(d-45))+0.000085 * 30 * d+0.09335 *$ LS

Ln fluids $(g)=-0.26360+0.18805 * d-0.001189 * d^{2}+0.13194 *$ LS

The weight of the placenta and uterine fluid is corrected for actual versus predicted litter weight at birth. A positive correlation between placental weight and birth weight is supported by results of Leenhouwers et al. (2002) and Van Rens et al. (2005). Therefore the weight of placenta and fluids is multiplied by the ratio between actual litter weight (litter size $\mathrm{x}$ birth weight, these are input data in the model) and predicted litter weight at birth (the value on $\mathrm{d} 115$ ) to correct for actual birth weight.

Energy in foetuses, placenta and fluids:

Energy retained in the foetuses, placenta and uterine fluids are calculated using the next equations:

Ln energy in foetuses $(k J)=10.77958-5.29435 * \exp (-0.02015 *(d-45))+0.000228 * 30 * d+0.06086 *$ LS

Ln energy in placenta $(\mathrm{kJ})=7.36942-1.18834 * \exp (-0.06812 *(\mathrm{~d}-45))+0.000187 * 30 * \mathrm{~d}+0.08959 *$ LS

Ln energy in fluids $(k J)=2.12564+0.11013 * d-0.000613 * d^{2}+0.08418 *$ LS

The results of these equations is multiplied by the ratio between actual litter birth weight (litter size $\mathrm{x}$ birth weight) and predicted litter weight at birth (the value on $d=115$ ) to correct for actual birth weight. The energy in foetuses is additionally corrected to a mean energy content of $3.6 \mathrm{MJ} / \mathrm{kg} \mathrm{BW}$ on day 115 as observed in a review of new born piglets (Everts and Dekker, 1994a).

Protein in foetuses, placenta and fluids:

Noblet et al. (1985) derived the following equations to predict protein retained in foetuses:

Ln protein in foetuses $(k J)=10.06598-5.03236 * \exp (-0.002116 *(d-45))+0.000299 * 30 * d+0.06397 *$ LS

NRC (2012) included results of Wu et al. (1999) to predict protein in the foetuses:

Ln protein in foetuses $(g)=8.729-12.5435 * \exp (-0.0145 * d)+0.0867 *$ LS .

This results in a slightly steeper curve and a little more protein retained in the foetuses than with the equation of Noblet et al. (1985). However, this difference is small when the equation of Noblet et al. 1985 ) is corrected for the current litter weight. Therefore the equation of Noblet et al. (1985) is used. To correct for actual birth weight and a protein concentration of $115 \mathrm{~g} / \mathrm{kg} \mathrm{BW}$ as observed as a mean protein content in new born pigs in a review of studies (Everts and Dekker, 1994a), protein in foetuses is multiplied by the ratio between actual protein mass (litter size $x$ birth weight $\times 115 \mathrm{~g} / \mathrm{kg}$ ) and predicted protein mass at birth (the value on $\mathrm{d} 115$ ).

Noblet et al. (1985) derived the following equations to predict protein retained in placenta and fluids:

Ln protein in placenta $(k J)=7.34264-1.40598 * \exp (-0.0625 *(d-45))+0.000253 * 30 * d+0.06339 *$ LS

Ln protein in fluids $(k J)=2.39536+0.09807 * d-0.000541 * d^{2}+0.08734 *$ LS 
NRC (2012) included results of McPherson et al. (2004) and derived an equation for the sum of nitrogen in placenta and uterine fluids. Comparison with the equations of Noblet et al. (1985) for a litter size of 12 pigs did not show any major differences, apart from a steeper increase in the curve described by NRC (2012) (Figure 4) (Bikker and Blok, 2017). Therefore the equation of Noblet et al. (1985) is used. To correct for actual birth weight, protein in placenta and fluids is multiplied by the ratio between actual litter weight (litter size $\mathrm{x}$ birth weight) and predicted litter weight at birth (the value on $d 115$ ).

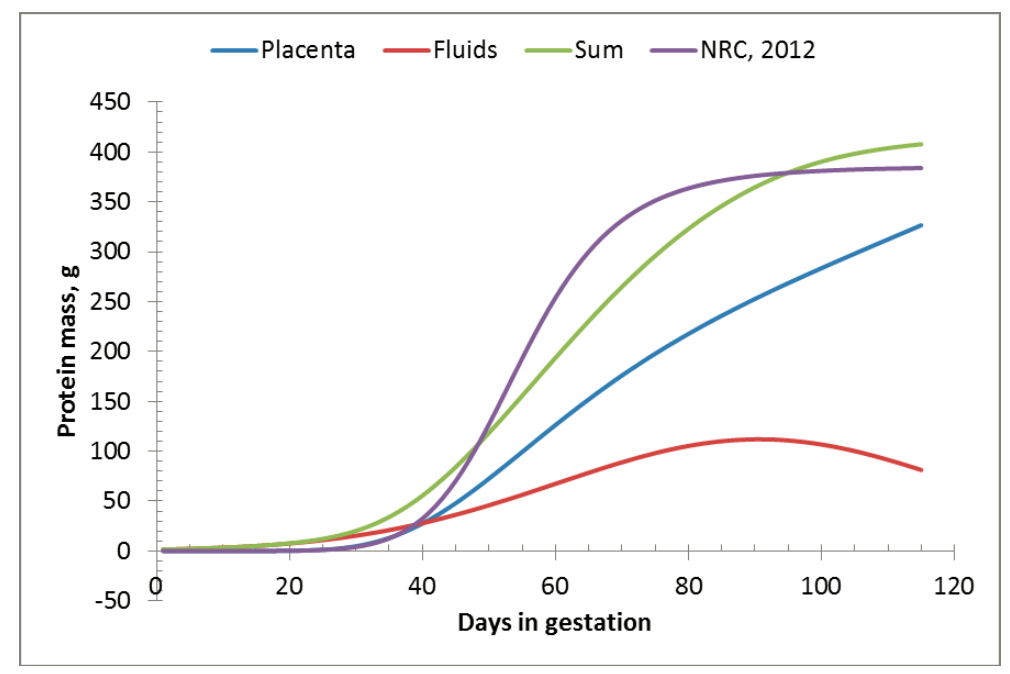

Figure 4 Protein mass in placenta, uterine fluids and their sum based on equations derived by Noblet et al. (1985) and by NRC (2012) (adopted from Bikker and Blok, 2017). The equation of Noblet et al. (1985) includes an effect of litter size and is based on a litter size of 12 piglets in the figure. The equation of NRC (2012) is derived from results with a litter size of 12 piglets, but corrected by the ratio between actual and predicted litter birth weight.

\subsection{Development of mammary tissue during gestation}

Weight of mammary tissue:

Noblet et al. (1985) derived the following equation based on 26 gilts to predict fresh weight of the mammary tissue:

Ln fresh weight $(g)=5.16091+0.07997 * \exp (0.04576 *(d-45))+0.05225 * 30$

More recent, Ji et al. (2006) developed equations based on 29 gilts to predict fresh weight of the mammary tissue. Fresh weight was fitted with 2 linear regressions to separately describe the slow increase during early gestation and rapid increase during late gestation. A break point (day of gestation) when the rates of accretion from both linear regressions changed at alpha $=0.05$ was identified on day 74 .

Fresh weight in the average individual mammary gland was estimated to increase by $1.4 \mathrm{~g} / \mathrm{d}$ until $\mathrm{d}$ 74 of gestation $[\mathrm{g}=103.66+1.4035 \times(\mathrm{d}-73.86) ; \mathrm{d}=$ day of gestation] and $4.8 \mathrm{~g} / \mathrm{d}$ after $\mathrm{d} 74$ of gestation $[\mathrm{g}=103.66+4.8204 \times(\mathrm{d}-73.86)]$. The number of glands per gilt ranged from 13 to 16 .

Ji et al. (2006) predict a higher weight of mammary tissue from day 42 up to day 105 than Noblet et al. (1985), and a similar weight on day 112, assuming 16 teats. We decided to use the equations of Ji et al. (2006) to predict the fresh weight of the mammary tissue. 
Energy in mammary tissue:

Noblet et al. (1985) derived the following equation to predict energy retained in mammary tissue: Ln energy in mammary tissue $(k J)=0.92380+6.89733 * \exp (0.00185 *(d-45))+0.06654 * 30$

This equation was used by Everts et al. (1994) but also by Feyera et al. (2017) as there are no recent data to predict the energy retention in mammary tissue. Therefore the equation of Noblet et al. (1985) is used.

Protein in mammary tissue:

In Everts et al. (2004) protein retention in mammary tissue is described by the equation derived from Noblet et al. (1985):

Ln protein in mammary tissue $(k J)=1.43401+3.32153 * \exp (0.00991 \times(d-45))+0.04803 \times 30$

Comparison with a recent serial slaughter study of Ji et al. $(2005,2006)$ suggested that the mammary protein content of contemporary sows may be substantially higher than predicted by the equation of Noblet et al. (1985) (Figure 5). Therefore, we adopted the following equation of NRC (2012) to describe the protein content in the mammary gland:

Ln protein mammary tissue $(g)=8.4827-7.1786 * \exp (-0.0153 *(d-29.18))$.

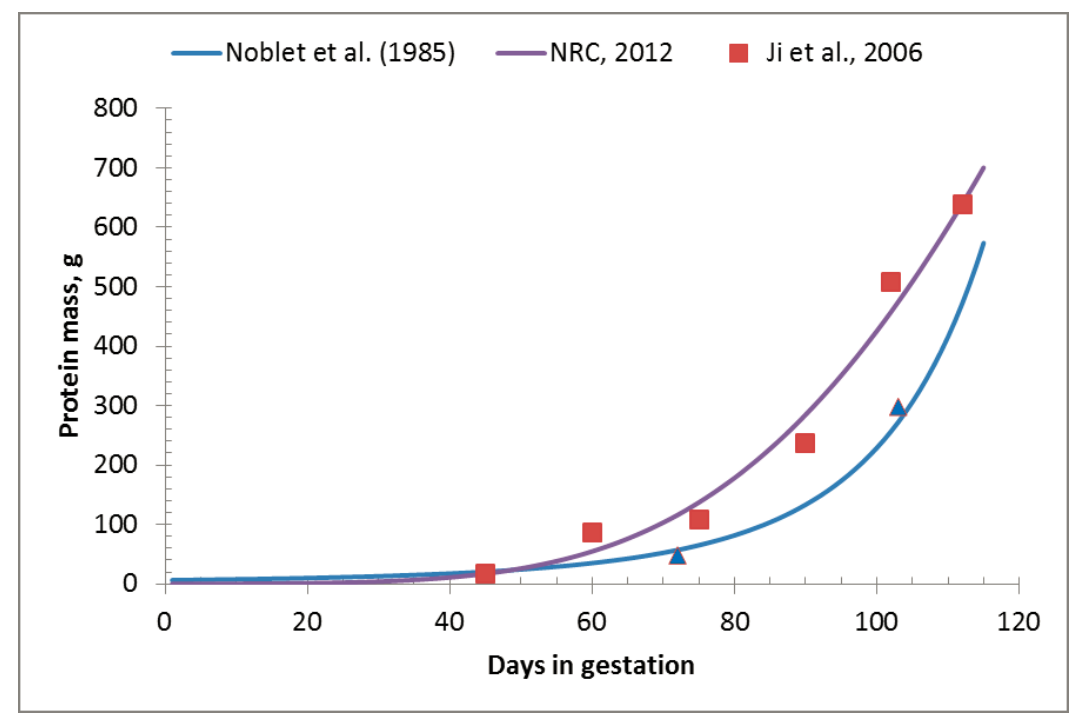

Figure 5 Protein mass in the mammary gland in studies of Noblet et al. (1985) and Ji et al. (2005, 2006) and simulated by equations from Noblet et al. (1985) and NRC (2012)(adopted from Bikker and Blok, 2017).

\subsection{Milk production and daily gain of the piglets after birth}

Daily milk production can be predicted from milk production curves or from rate and composition of daily body gain of the piglets after birth. In Everts et al. (1995), daily milk production was predicted from litter size, daily litter gain and body composition of the piglets. The authors did not predict the daily milk production from milk production curves because they considered that these curves have different sources of errors and might not be accurate enough.

\subsubsection{Milk production curves}

Dourmad et al. (2008) used a curve proposed by Whittemore and Morgan (1990) to estimate milk production throughout lactation. This curve was based on milk yield data obtained by the weighsuckle-weigh (WSW) technique. Using this method, the litter is separated from the sow on selected days of lactation, allowed to suckle during regular intervals and weighed before and after each suckling to calculate the milk production from the immediate increase in body weight. Milk production has to be corrected for the weight losses due to evaporation and metabolism during suckling and for losses through faeces and urine. In literature different equations are used to correct the milk 
production for these factors. Moreover, milk production is not always corrected for all these factors. For instance, Theil et al. (2002b) corrected milk production for metabolic, salivary and evaporative losses during suckling and for weight loss during suckling due to activity but correction of milk production for additional losses of weight due to defecation and urination were not performed because defecation and urination were minimized during suckling.

Theil et al. (2002b) compared milk production measured by the WSW method and by the deuterium oxide $\left(D_{2} O\right)$ isotope dilution technique. With the $D_{2} \mathrm{O}$ technique, the milk intake of a piglet is calculated as the sum of the water turnover and the potential metabolic water stored, divided by the potential water fraction of the milk. To determine the magnitude of isotopic recycling, a randomly selected piglet in each litter is not enriched with $\mathrm{D}_{2} \mathrm{O}$ (Theil et al., 2002b). In the study of Theil et al. (2002b) the milk production found by the WSW method was $12.7 \%$ lower than that found by the $\mathrm{D}_{2} \mathrm{O}$ dilution technique.

Hansen et al. (2012) used the data from 21 peer reviewed publications and individual sow data from 3 studies to predict milk production curves. In 8 studies, milk production was measured by WSW and in 13 studies with the $\mathrm{D}_{2} \mathrm{O}$ dilution technique. The authors concluded that WSW underestimated the milk production with about $26 \%$ compared to the $\mathrm{D}_{2} \mathrm{O}$ dilution technique. The underestimation can be ascribed to reduced milk intake by the piglets because of the interruption of nursing and losses through evaporation, urine, faeces, and saliva during suckling (Klaver et al., 1981; Theil et al., 2002b). Hanssen et al. (2012) suggested that WSW should not be used if the absolute quantities of milk yield are the focus because of the underestimation of milk production.

Hansen et al. (2012) used the following equations to predict the milk production curves:

- Natural logarithm of the milk yield at d 5 (ly5), d 20 (ly20), and d 30 (ly30):

$$
\begin{array}{ll}
\circ & \text { ly } 5=1.93+0.07 \times(\text { Litter size }-9.5)+0.04 \times(\text { Litter gain }-2.05) \\
\circ & \text { ly20 }=2.23+0.05 \times(\text { Litter size }-9.5)+0.23 \times(\text { Litter gain }-2.05) \\
\circ & \text { ly30 }=2.15+0.02 \times(\text { Litter size }-9.5)+0.31 \times(\text { Litter gain }-2.05)
\end{array}
$$

- $\quad a=\exp (1 / 3 \times(-\operatorname{ly} 20 \times \log (128 / 27)-3 \times \log (20) \times \operatorname{ly} 30+5 \times \log (20) \times \operatorname{ly} 20-2 \times \log (20) \times$ ly $5+4 \times \operatorname{ly} 5 \times \log (128 / 27)+12 \times \operatorname{ly} 30 \times \log (5)-20 \times \log (5) \times \operatorname{ly} 20+8 \times \log (5) \times$ ly5)/ $\log (128 / 27))$

- $\quad b=-(3 \times \operatorname{ly} 30-5 \times \operatorname{ly} 20+2 \times \operatorname{ly} 5) / \log (128 / 27)$

- $\quad c=1 / 15 \times(\operatorname{ly} 5 \times \log (128 / 27)-\operatorname{ly} 20 \times \log (128 / 27)-3 \times \log (20) \times \operatorname{ly} 30+5 \times \log (20) \times \operatorname{ly} 20-2$ $\times \log (20) \times \operatorname{ly} 5+3 \times \operatorname{ly} 30 \times \log (5)-5 \times \log (5) \times \operatorname{ly} 20+2 \times \log (5) \times \operatorname{ly} 5) / \log (128 / 27)$

- $\quad$ Milk yield $(\mathrm{kg} / \mathrm{d})=\mathrm{a} \times \mathrm{t}^{\mathrm{b}} \times \exp (-\mathrm{c} \times \mathrm{t})$ in which $\mathrm{t}=$ day of lactation

To give an indication of milk production yields, in Figure 6 four milk production curves with changing litter size and/or litter gain are presented as calculated by Hansen et al. (2012).

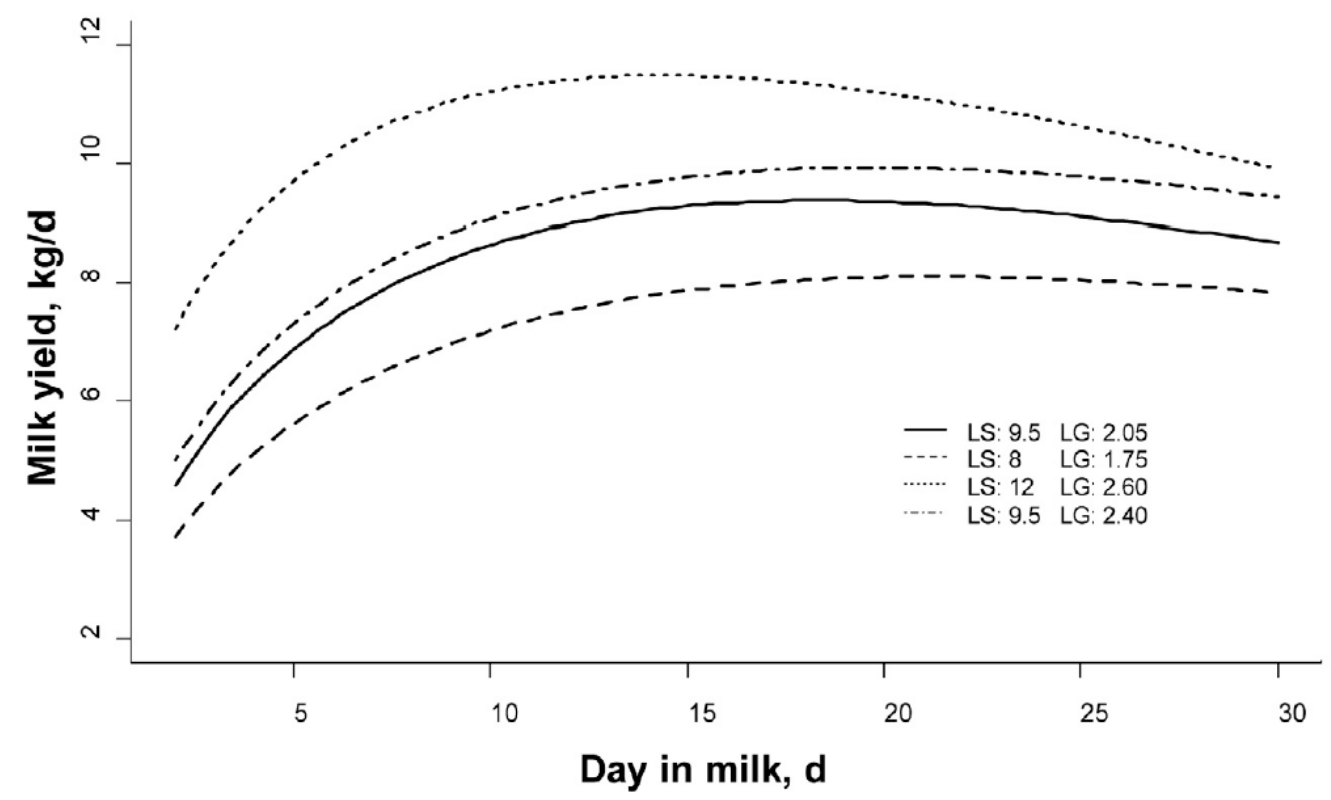

Figure 6 Comparison of lactation curves with changing litter gain (LG) and litter size (LS) (Hansen et al., 2012). 


\subsubsection{Daily gain of the suckling piglets}

Daily output of milk energy and protein/amino acids and daily milk production can be predicted from milk production curves as described in chapter 2.5.1. but these can also be predicted from litter size, mean daily litter gain and body composition of the piglets. Litter size and mean daily litter gain are input factors in the model. To predict the weekly energy and protein/amino acid requirement of lactating sows, it is necessary to know the daily gain of suckling piglets, that received no creep feed, per week of the lactation. Everts et al. (1995) assumed that the daily gain of no creep feed fed suckling piglets per week of lactation, expressed as percentage of the mean daily gain during lactation, was $80,105,110$ and $105 \%$ in week 1, 2, 3 and 4 of lactation, respectively. In literature only a few data are available on the weekly daily gain of suckling piglets. In a study of Devillers et al. (2011), daily gain of the suckling piglets was 85,103, 109 and $103 \%$ in week 1, 2, 3 and 4 of lactation, respectively. In a trial of Wattakanul et al (2005), daily gain of creep feed fed suckling piglets was $91,91,106$ and $112 \%$ in week 1, 2, 3 and 4 of lactation, respectively. In week 4 of lactation, the suckling piglets consumed $25 \mathrm{~g}$ of creep feed per day and this probably explains the higher daily gain in week 4 compared to week 3 . In a study of Bikker (unpublished results), daily gain of no creep feed fed pigs was $85,115,115$ and $85 \%$ in week $1,2,3$ and 4 of lactation, respectively. As in general, milk production of the sows is lower in week 4 than in week 3 of lactation (Hansen et al., 2012), it is logic that daily gain of no creep feed fed pigs is lower in week 4 than in week 3 of lactation. Based on the literature data on daily gain of suckling piglets and based on the milk production curves predicted by Hansen et al. (2012), we decided to predict the weekly daily gain of the suckling piglets, expressed as percentage of the mean daily gain during lactation, as $85,110,110$ and $95 \%$ in week $1,2,3$ and 4 of lactation, respectively.

\subsubsection{Milk production curves vs daily gain of the piglets}

Both methods to predict daily milk production contain assumptions and inaccuracies. In general, with both methods predicted milk production rapidly increases in the first week of lactation and remains more or less constant in week 2 and 3 of lactation. In week 4, milk production decreases especially in sows with a high litter size and a high daily litter gain.

Because of the inaccuracies in milk production curves and because the milk production curves are mathematical equations which are not based on biological mechanisms in the pig, we prefer to predict daily milk production from litter size, mean daily litter gain and body composition like Everts et al. (1995) and to predict the weekly daily gain of the suckling piglets, expressed as percentage of the mean daily gain during lactation, as $85,110,110$ and $95 \%$ in week 1, 2, 3 and 4 of lactation, respectively. However, we also decided to predict the daily milk production with the milk production curves from Hansen et al. (2012), because several authors (Hansen et al., 2014; Strathe et al., 2015; Feyera and Theil, 2017; Gauthier et al., 2019) are using these equations. In chapter 5.2, we will present energy and amino acid requirements during lactation based on both methods and illustrate the differences.

\subsection{Body composition of the suckling piglets}

From the birth and weaning weight of the piglets and the protein and fat content of the piglets at birth and at weaning, the protein and fat deposition per $\mathrm{kg}$ of daily gain can be predicted. Based on Everts and Dekker (1994b), Everts et al. (1995) predicted protein deposition in suckling piglets to be $160 \mathrm{~g}$ per $\mathrm{kg}$ daily gain. Protein deposition per $\mathrm{kg}$ daily gain was not affected by average daily gain (ADG) (Everts and Dekker, 1994b). Recently, Bikker et al. (2018) determined a protein deposition of $155 \mathrm{~g}$ per kg daily gain in three week old piglets, which is comparable with the prediction of Everts et al. (1995). In another trial, Bikker et al. (unpublished results) observed a protein deposition of $158 \mathrm{~g}$ per $\mathrm{kg}$ daily gain in four week old piglets, which is also comparable with the prediction of Everts et al. (1995). RVO (mestbeleid 2019-2021) also adopted a protein deposition in suckling piglets of $160 \mathrm{~g}$ protein per kg daily gain. Therefore, we decided to use the equation of Everts et al. (1995) to predict protein deposition per $\mathrm{kg}$ daily gain:

Protein deposition per piglet $(\mathrm{g} / \mathrm{d})=160 \times$ daily gain $(\mathrm{kg} / \mathrm{d})$.

In contrast to protein deposition, fat deposition is affected by the rate of ADG (Everts and Dekker, 1994b). The fat content per $\mathrm{kg}$ of gain increases with increasing daily gain. Based on Everts and Dekker (1994b), Everts et al. (1995) predicted fat deposition in suckling piglets as: 
Fat deposition per piglet $(\mathrm{g} / \mathrm{kg})=135+140 \times$ ADG $(\mathrm{kg} / \mathrm{d})$.

Recently, Bikker et al. (2018) analysed the body composition of piglets at birth and at an age of three weeks, from which the mothers were fed a low or a high phosphorus $(P)$ diet during both gestation and lactation. From these data, it can be calculated that the fat deposition in the piglets from birth till an age of three weeks was 171 and $167 \mathrm{~g}$ per kg daily gain on the low and high $\mathrm{P}$ diet, respectively. Daily gain of the piglets in the low and high P diet was 241 and $253 \mathrm{~g} / \mathrm{d}$, respectively. With the equation of Everts et al. (1995), it can be calculated that the fat deposition of these piglets is 169 $(135+140 \times 0.241)$ and $170 \mathrm{~g}$ per kg gain, respectively, which is very similar to the actual results of Bikker et al. (2018). In another trial, Bikker et al. (unpublished results) analysed the body composition of piglets at birth and at age of 27 days. From these data, it was calculated that the fat deposition in the piglets from birth till an age of four weeks was $162 \mathrm{~g}$ per $\mathrm{kg}$ daily gain. Daily gain of the piglets was $231 \mathrm{~g} / \mathrm{d}$. With the equation of Everts et al. (1995), the fat deposition of these piglets is $167(135+140 \times 0.231) \mathrm{g}$ per $\mathrm{kg}$ gain, which is very similar to the actual results of Bikker et al. (unpublished results).

Based on these results, we decided to use the equation of Everts et al. (1995) to predict fat deposition:

Fat deposition per piglet $(\mathrm{g} / \mathrm{kg})=135+140 \times$ daily gain $(\mathrm{kg} / \mathrm{d})$;

Fat deposition per piglet $(\mathrm{g} / \mathrm{d})=$ daily gain $(\mathrm{kg} / \mathrm{d}) \times(135+140 \times$ daily gain $(\mathrm{kg} / \mathrm{d}))$.

\subsection{Milk composition}

Everts et al. (1995) calculated the protein, fat and lactose content in milk based on seven published studies. The milk protein content in these seven studies varied from 4.6 to $5.7 \%$, the fat content from 6.1 to $10.5 \%$ and the lactose content from 5.2 to $5.9 \%$. The variation in fat content in milk is highest and depends on the feed intake of the sows during lactation and the percentage of fat in the diet. In these seven studies, the mean content of protein, fat and lactose in milk during lactation was 5.2, 7.2 and $5.5 \%$, respectively. The mean energy content was $5.0 \mathrm{MJ}$ per kg of milk (Everts et al., 1995). More recent, Hansen et al. (2012) calculated the protein, fat and lactose content in milk based on 27 studies published in peer reviewed journals from 1982 till 2012. The mean content of protein, fat and lactose in milk during lactation was 5.22, 7.32 and $5.41 \%$, which is comparable with the milk composition in Everts et al. (1995). Hansen et al. (2012) calculated the mean energy content in milk with the following equation: Energy content milk $(\mathrm{MJ} / \mathrm{kg})=0.239 \times$ protein $\%+0.389 \times$ fat $\%+$ $0.165 \times$ lactose\%. This results in a mean energy content of $4.99 \mathrm{MJ}$ per $\mathrm{kg}$ of milk, which is very similar to the value of 5.0 MJ per kg milk as calculated by Everts et al. (1995).

Milk composition, however, is not constant during lactation (Everts et al., 1995; Hansen et al., 2012). Milk fat and milk protein content in general decrease during the course of lactation, especially during the first two weeks, whereas milk lactose content increases during lactation. Hansen et al. (2012) described the content of protein, fat, lactose and energy in milk during lactation with the following equations:

1. Protein content $(\%)=5.18+4.43 \times$ (day of lactation-1 -0.107$)+0.07 \times($ crude protein $(\%)$ in diet - 15.9) (we adopted a crude protein content in the lactation diet of $16 \%$ )

2. Fat content $(\%)=7.3-0.065 \times$ (day of lactation -13.3 )

3. Lactose content $(\%)=5.38+0.01 \times$ (day of lactation -15.8 )

4. Energy content $(\mathrm{MJ} / \mathrm{kg})=0.389 \times$ fat $(\%)+0.239 \times$ protein $(\%)+0.165 \times$ lactose $(\%)$;

We decided to use these four formulas to calculate the energy content (MJ) per kg of milk in week 1 , 2, 3 and 4 of lactation, which means a decreasing energy content of milk during the course of lactation, instead of using a mean energy content of $5.0 \mathrm{MJ}$ per $\mathrm{kg}$ of milk during the whole lactation as adopted by Everts et al. (1995).

\subsection{Mobilisation during lactation}

In Table 1 (chapter 2.1), the sows have been defined by their body weight and backfat thickness at mating and at farrowing. From these characteristics, the protein and lipid mass were calculated and the loss of body weight, protein and fat during lactation, as described in chapter 2.1 and Appendix 1. 
We assumed a constant daily loss of body weight, protein and fat during lactation because of lack of data about the weekly loss during lactation. 


\section{Energy metabolism}

\subsection{Energy metabolism during gestation}

\subsubsection{Maintenance requirements}

Under thermoneutral conditions and with moderate physical activity, ME for maintenance (MEm) varies between 400 and 460 kJ per kg BW ${ }^{0.75}$ (Noblet et al., 1990; Everts et al., 1994; Dourmad et al., 2008). When expressed per $\mathrm{kg} \mathrm{BW}{ }^{0.75}, \mathrm{ME}_{\mathrm{m}}$ is very similar in primiparous and mulitparous sows and can be considered as constant over gestation (Dourmad et al., 2008). Therefore, a constant $\mathrm{ME}_{\mathrm{m}}$ requirement of $440 \mathrm{~kJ}$ per $\mathrm{kg} \mathrm{BW} \mathrm{BW}^{0.75}$ was used in the model of Noblet et al. (1990) and thereafter in the models of Everts et al. (1994), Dourmad et al. (2008) and NRC (2012). Ball et al. (2008) suggested that this equation to predict $\mathrm{MEm}_{\mathrm{m}}$ is too low for the current high prolific sows. These authors indicate that $\mathrm{MEm}_{\mathrm{m}}$ is about $14 \%$ higher and should be $506 \mathrm{KJ}$ per $\mathrm{kg} \mathrm{BW} \mathrm{BW}^{0.75}$. This value was based on research with 5 sows only and has not been implemented by the NRC (2012). Therefore, we decided to use the equation of Noblet et al. (1990): $\mathrm{ME}_{\mathrm{m}}=440 \mathrm{~kJ}$ per $\mathrm{kg} \mathrm{BW} \mathrm{BW}^{0.75}$.

\subsubsection{Efficiency of energy utilization}

The efficiencies of ME for maternal protein deposition $\left(\mathrm{k}_{\mathrm{p}}\right)$, maternal fat deposition $\left(\mathrm{k}_{\mathrm{f}}\right)$ and uterine growth $\left(k_{c}\right)$ are used to determine the amount of ME required for maternal protein and fat deposition and for uterine growth, respectively. Energy requirement for maintenance and efficiencies of energy utilization are highly correlated (Everts et al., 1994). Because we use the equation for $\mathrm{ME}_{\mathrm{m}}$ from Noblet et al. (1990), we also use the values for $k_{p}=0.60, k_{f}=0.80$ and $k_{c}=0.50$ derived by Noblet et al. (1990). These efficiencies were also used by Everts et al. (1994) and Dourmad et al. (2008).

\subsection{Energy metabolism during lactation}

\subsubsection{Maintenance requirements lactating sows}

During lactation, the energy requirement for maintenance $\left(\mathrm{ME}_{\mathrm{m}}\right)$ was estimated to be $460 \mathrm{~kJ}$ per $\mathrm{kg}$ BW $^{0.75}$ (Noblet et al., 1990). The authors assumed that lactating sows do not need extra energy for thermoregulation and physical activity. Dourmad et al. (2008) also adopted the energy requirement for maintenance in lactating sows as $460 \mathrm{~kJ}$ per kg BW ${ }^{0.75}$. Theil et al. (2004) estimated MEm to be 482 $\mathrm{kJ}$ per $\mathrm{kg} \mathrm{BW}{ }^{0.75}$, which is slightly higher than the $\mathrm{ME}_{\mathrm{m}}$ reported by Noblet et al. (1990). They suggested that these differences might be related to the different methods for separating sow heat production from the total (sow + litter) heat production. Everts et al. (1995) and NRC (2012) assumed the maintenance requirement for lactating sows to be $\mathrm{ME}_{\mathrm{m}}=440 \mathrm{~kJ}$ per $\mathrm{kg} \mathrm{BW} \mathrm{W}^{0.75}$, similar as in gestating sows. Because we used the equation from Noblet et al. (1990) to calculate $M E_{m}$ for the gestating sows, we also adopted their equation to calculate $M E_{m}$ for the lactating sows: $M E_{m}=460 \mathrm{~kJ}$ per $\mathrm{kg} \mathrm{BW} \mathrm{BW}^{0.75}$.

\subsubsection{Efficiency of energy utilization for milk production}

The estimated efficiency of dietary ME for milk production $\left(\mathrm{Km}_{\mathrm{m}}\right)$ varies between 68 and $79 \%$ (Everts et al., 1995; Dourmad et al., 2008). According to Noblet and Etienne (1987) and Noblet et al. (1990), km is 0.72 . When energy from body reserves is used for milk production the estimated efficiency $\left(k_{r m}\right)$ is 0.88 . This efficiency is higher than $\mathrm{k}_{\mathrm{m}}$ because mainly lipids are mobilised from body reserves and these are directly transferred to milk, which occurs with a high metabolic efficiency (Noblet and Etienne, 1987).

Because we adopted the equation for $\mathrm{ME}_{\mathrm{m}}$ from Noblet et al. (1990), we also adopted the values for $\mathrm{km}_{\mathrm{m}}$ $=0.72$ and $\mathrm{k}_{\mathrm{rm}}=0.88$ derived by Noblet and Etienne (1987) and Noblet et al. (1990). These efficiencies were also used by Everts et al. (1995), Dourmad et al. (2008) and Hansen et al. (2014). 


\subsubsection{Energy requirement of suckling piglets}

Piglets needs energy from milk for maintenance and for daily gain. Everts et al. (1995) assumed that the energy requirement for maintenance $\left(M E_{m}\right)$ for suckling piglets is $440 \mathrm{~kJ}$ per $\mathrm{kg} \mathrm{BW} \mathrm{BW}^{0.75}$. This was based on research of Campbell and Dunkin (1983). Because of a lack of data on $\mathrm{ME}_{\mathrm{m}}$ for suckling piglets and because the influence of $\mathrm{MEm}_{\mathrm{m}}$ for suckling piglets on milk production is rather low, we decided to use the same equation as Everts et al. (1995).

The energy requirement for daily gain depends on the daily protein and fat deposition in the piglets and the energetic efficiency of ME in milk for daily gain. The daily protein and fat deposition in piglets was described in chapter 2.5.2. Everts et al. (1995) assumed that the energetic efficiency of ME in milk for daily gain of the piglets is 0.78, based on Mullan et al. (1993). Pluske and Dong (1998) also assume that ME in milk for piglet gain is used with an efficiency of 0.75 to 0.80 . As there is no new information, we decided to use an efficiency of 0.78 . This means that the energy requirement for the daily gain of suckling piglets can be calculated with the following equation:

Energy requirement for daily gain $(\mathrm{kJ} / \mathrm{d})=($ protein deposition $\times 23.8+$ fat deposition $\times 39.5) / 0.78$

In which: 23.8 is energy content $(\mathrm{kJ})$ of 1 gram protein, 39.5 is energy content $(\mathrm{kJ})$ of $1 \mathrm{~g}$ fat, 0.78 is efficiency of ME in milk for daily gain.

The daily energy requirement of piglets from milk is calculated with the following equation:

Daily energy requirement from milk per litter $(M J / d)=\left(\left(M E_{m}+\right.\right.$ energy requirement for daily gain $) x$ litter size $) /(0.93 \times 1000)$

In which: 0.93 is the metabolizability of milk (the energy digestibility of milk is about $97 \%$ (CVB, 2018) and the ratio between digestible and metabolizable energy is 0.96 (Everts et al., 1995); $0.97 \mathrm{x}$ $0.96=0.93)$.

The daily milk production is calculated with the following equation:

Daily milk production $(\mathrm{kg} / \mathrm{d})$ = daily energy requirement from milk per litter $(\mathrm{MJ} / \mathrm{d})$ / energy content of milk $(\mathrm{MJ} / \mathrm{kg})$ 


\section{Amino acid metabolism}

\subsection{Amino acid metabolism during gestation}

\subsubsection{Maintenance requirements}

The main determinants of amino acid requirements for maintenance include the basal intestinal endogenous losses of amino acids, which are related to the level of feed intake, the amino acid losses from skin and hair, which are a function of the metabolic body weight (BW ${ }^{0.75}$ ) (Moughan, 1999; NRC, 2012) and minimum protein turnover. Everts et al. (1994) and Dourmad et al. (2008) have not subdivided maintenance requirements in basal and integument losses and minimum protein turnover but calculated maintenance requirements as obligatory losses of amino acids based on research of Fuller et al. (1989) with growing pigs. For lysine, Dourmad et al. (2008) and Everts et al. (1994) calculated maintenance requirement as $36 \mathrm{mg}$ per $\mathrm{kg} \mathrm{BW} \mathrm{BW}^{0.75}$ and $36 \mathrm{mg}$ per $\mathrm{kg} \mathrm{BW}^{0.75} / 0.7$, respectively ( 0.7 is efficiency factor for lysine based on the efficiency factor in growing-finishing pigs (Werkgroep TMV, 1991).

There are limited data on the profile of intestinal amino acid losses for gestating sows. NRC (2012), therefore, assumed the amino acid profile of the intestinal endogenous losses in sows to be similar to that of the growing-finishing pig (which was an average from 57 studies with ileally cannulated growing-finishing pigs reported in literature). This profile was related to ileal lysine losses determined in restrictedly fed gestating sows $(0.522 \mathrm{~g} / \mathrm{kg}$ dry matter (DM) intake; Stein et al., 1999) to calculate the intestinal losses for each of the essential amino acids (see Table 3). The ileal intestinal endogenous losses were increased by $10 \%$ to include the contribution from large intestinal losses (NRC, 2012; Moughan, 1999). Stein et al. (1999) measured basal endogenous losses in restricted fed $(2.0 \mathrm{~kg} / \mathrm{d})$ and ad libitum fed $(4.35 \mathrm{~kg} / \mathrm{d})$ gestating sows. Basal endogenous losses in the restricted and ad libitum fed gestating sows were 0.522 and $0.413 \mathrm{~g} / \mathrm{kg}$ DM intake, respectively. We decided to use the amino acid profile of endogenous amino acid losses of the NRC (2012) but relate this to the mean of the endogenous lysine losses in restricted and ad libitum fed gestating sows $(0.468 \mathrm{~g} / \mathrm{kg} \mathrm{DM}$ intake) as the mean feed intake of the sows in the Netherlands is around $2.9 \mathrm{~kg} / \mathrm{d}$.

Amino acid composition of skin and hair in growing-finishing pigs has been reported by Moughan (1999) (Table 3). Van Milgen et al. (2008) used this profile for growing-finishing pigs and NRC (2012) used this profile for sows. We also decide to use this profile for sows.

In addition to endogenous and integument losses of amino acid, minimum (inevitable) amino acid catabolism also contributes to maintenance amino acid requirements. No literature is available on amino acid catabolism associated with body maintenance functions in sows. For this reason, NRC (2012) applied an inefficiency factor taking into account the use of dietary amino acids to meet the requirements for maintenance, which also covers amino acid catabolism. The efficiency of lysine (0.75) was derived from observations on individual growing pigs and this efficiency seems to be independent of BW (Dourmad et al., 1996). For the other amino acids, values were adjusted in order to match observed amino acid requirements in empirical studies with model predicted requirements. In InraPorc (Van Milgen et al., 2008), the values for the amino acid losses due to a minimum protein turnover were calculated for growing pigs from those reported by Moughan (1999) (see Table 3). We decided to use these data also for sows.

Moughan (1999) assumed that the SID amino acids were used with an efficiency of $90 \%$ for maintenance (amino acid losses and minimum amino acids turnover). We adopted this efficiency. 
Basal ileal endogenous losses ( $\mathrm{g} / \mathrm{kg}$ DM intake), hair and skin losses (in $\mathrm{mg} / \mathrm{kg} \mathrm{BW}$. $75 / \mathrm{d}$ ) and minimum amino acid turnover (in $\mathrm{mg} / \mathrm{kg} \mathrm{BW}$. $75 / \mathrm{d}$ ) of lysine, amino acid composition of these losses ( $\mathrm{g} / 100 \mathrm{~g}$ lysine) and efficiency of amino acids for maintenance.

\begin{tabular}{|c|c|c|c|c|c|c|}
\hline & $\begin{array}{c}\text { Basal ileal } \\
\text { endogenous } \\
\text { losses } \\
\text { (g/kg DM } \\
\text { intake)| }{ }^{1}\end{array}$ & $\begin{array}{c}\text { Basal ileal } \\
\text { endogenous } \\
\text { losses } \\
\text { (g/kg DM } \\
\text { intake)/2 }\end{array}$ & $\begin{array}{c}\text { Hair and } \\
\text { skin } \\
(\mathrm{mg} / \mathrm{kg} \\
\left.\mathrm{B} \mathrm{W}^{0.75} / \mathrm{d}\right)^{3}\end{array}$ & $\begin{array}{c}\text { Minimum } \\
\text { turnover } \\
\text { (lysine in } \\
\text { mg/kg } \\
\left.\text { BW }^{0.75} / \mathrm{d}\right)^{4}\end{array}$ & Efficiëncy ${ }^{5}$ & Efficiëncy ${ }^{6}$ \\
\hline Lysine & $0.522 / 0.413$ & 0.522 & 4.04 & 21.9 & 0.750 & 0.9 \\
\hline Lysine & 100 & 100 & 100 & 100 & 0.750 & 0.9 \\
\hline Threonine & 116.1 & 145.1 & 74.4 & 55.2 & 0.807 & 0.9 \\
\hline Tryptophan & 31.0 & 31.8 & 20.9 & 13.1 & 0.714 & 0.9 \\
\hline Isoleucine & 72.0 & 91.9 & 55.8 & 54.5 & 0.751 & 0.9 \\
\hline Valine & 101.9 & 129.8 & 83.7 & 69.0 & 0.841 & 0.9 \\
\hline Leucine & 123.4 & 125.9 & 116.3 & 100.9 & 0.900 & 0.9 \\
\hline Histidine & 42.5 & 48.7 & 27.9 & 46.6 & 0.973 & 0.9 \\
\hline
\end{tabular}

${ }^{1}$ Stein et al. (1999): restricted/ad libitum fed gestating sows; ${ }^{2}$ NRC (2012): endogenous losses of lysine is based on restricted fed gestating sows in Stein et al. (1999); amino acid profile of the intestinal endogenous losses is an average from 57 studies with ileally cannulated growing-finishing pigs reported in literature; ${ }^{3}$ Moughan (1999): measured in growingfinishing pigs; estimated from an integumental protein loss of $94 \mathrm{mg}$ protein/ $\mathrm{BW}^{0.75} / \mathrm{d} ;{ }^{4}$ Moughan (1999): measured in growing-finishing pigs; estimated from a basal body protein loss of $325 \mathrm{mg}$ protein/ $\mathrm{BW}^{0.75} / \mathrm{d} ;{ }^{5} \mathrm{NRC}(2012) ;{ }^{6}$ Moughan (1999)

As it is generally accepted that amino acid requirements for maintenance include basal intestinal endogenous amino acid losses, skin and hair amino acid losses, and minimum protein turnover, we calculate amino acids requirement for maintenance as follows:

SID Lysine requirement $(\mathrm{g} / \mathrm{d})=\left((0.468 \times 1.1 \times \mathrm{DM}\right.$ intake $\left.)+0.00404 \times \mathrm{BW}^{0.75}+0.0219 \times \mathrm{BW}^{0.75}\right) /$ 0.9

In which: basal endogenous loss of lysine is based on the mean value measured in restricted and ad libitum fed gestating sows in Stein et al. (1999), amino acid profile of the basal endogenous losses is based on NRC (2012) and hair and skin losses, minimum protein turnover and the efficiency of amino acids for maintenance are based on Moughan (1999). Since DM-intake in the model is unknown, we used the predicted NE-requirement per day to calculate endogenous losses from the digestive tract, thus assuming that the feed allowance equals the requirements.

For a sow of $200 \mathrm{~kg}$ and a DM intake of $2.5 \mathrm{~kg} / \mathrm{d}$, this means a SID lysine requirement for maintenance from $2.96 \mathrm{~g} / \mathrm{d}$, which is in good agreement with the lysine requirement from $2.73 \mathrm{~g} / \mathrm{d}$ calculated by Everts et al. (1994).

\subsubsection{Amino acid composition of gestational protein pools}

During gestation amino acids are required for maternal protein deposition and for protein deposited in the foetuses, placenta, fluids and mammary tissue. In the InraPorc model, Dourmad et al. (2008) used one constant ideal amino acid profile in the diet for gestation (Table 4). This ideal amino acid profile was not obtained from a factorial approach but from a literature review of empirical data. Everts et al. (1994) used separate amino acid profiles for retained maternal protein (including the udder) and foetal protein. In NRC (2012), each protein pool has its own amino acid profile.

\section{Maternal body protein}

Everts and Dekker (1995a; 1995b) analysed the amino acid composition of maternal body protein (excluding foetuses and uterus but including the udder) in six parity 1 sows at day 108 of gestation and in four parity 3 sows after weaning. The amino acid composition of the parity 1 and parity 3 sows were similar and therefore the mean amino acid composition was used in Everts et al. (1994) (Table 4). These data were also used by NRC (2012) as there are no recent data available. We also use these data.

\section{Foetal protein}

Everts et al. (1995a) analysed the amino acid composition of eight unborn piglets at day 108 of gestation (Table 4). More recent, Wu et al. (1999) analysed the amino acid composition of 27 foetal 
piglets on day 40,60,90, 110 and 114 of gestation. NRC (2012) regressed the mass of each amino acid against the foetal protein body mass on day 40,60,90, 108 and 114 of gestation. The product of 100 and the slope of the linear regression, with a forced intercept of 0 , was taken as the amino acid profile for foetal piglets (NRC, 2012) (Table 4). Because the amino acid composition of the foetal piglets in NRC (2012) is based on a total of 27 foetal piglets, analysed on several moments during gestation, we decided to use the NRC (2012) foetal amino acid profile.

\section{Placental and fluid protein}

As there were no published data on amino acid composition for placenta across stage of gestation in sows, NRC (2012) analysed placental tissue from a total of 22 gilts on day 43, 57-58, 90-92 and 100109 of gestation. The mean amino acid concentration was determined over days in gestation to represent one amino acid profile. Amino acid composition of fluid was based on Wu et al. (1995). Because placental protein represents approximately $96 \%$ of the total placenta plus fluid proteins, total amino acid profile was estimated using $96 \%$ of placenta amino acid and $4 \%$ of fluid (NRC, 2012) (Table 4). We use the amino acid profile as estimated by NRC (2012).

\section{Mammary tissue protein}

As there were no published data on amino acid composition in mammary tissue across stage of gestation, NRC (2012) analysed mammary tissue samples of in total 22 gilts on day 80, 100 and 110 of gestation. The amino acid mass per gland was calculated based on the amino acid composition of the mammary protein and the protein content per gland. Mass of each amino acid was regressed against the mammary protein mass per gland on days 80, 100 and 110 of gestation to generate amino acid composition of mammary gland protein gain. The amino acid composition of the mammary protein gain across gestation was based on the slope of the regression line, as carried out for amino acid composition of the foetal protein gain (NRC, 2012) (Table 4). We use this amino acid profile.

\section{Ideal amino acid profile during gestation}

As mentioned earlier, in the InraPorc model, Dourmad et al. (2008) used one constant ideal amino acid profile in the diet for gestation (Table 4) based on a literature review of empirical data. Van Milgen and Dourmad (2015) determined the ideal amino acid profile in the diet for gestating sows with the NRC model (2012) (Table 4) and compared this with the ideal amino acid profile used in InraPorc (Dourmad et al., 2008). With the exception of isoleucine, the ideal profiles used by InraPorc and NRC are very similar. Based on a series of studies, Kim et al. (2009) suggested ideal ratios for SID Lys:Thr:Ile:Val:Leu:His:Phe of 100:79:59:65:88:32:50 for day 0 to 60 of gestation and of $100: 71: 56: 66: 95: 36: 52$ for day 60 to 114 of gestation. The SID threonine to lysine ratio decreases during gestation, whereas the SID leucine to lysine ratio increases. With the exception of valine, the ideal profile suggested by Kim et al.,(2009) is quite comparable with those suggested by InraPorc (Dourmad et al., 2008) and NRC (2012). We decided to use the ideal amino acid profile in the diet during gestation of Dourmad et al. (2008). 

protein gain, placenta protein and protein retained in the udder and ideal amino acid profile in the diet during gestation.

\begin{tabular}{|c|c|c|c|c|c|c|c|}
\hline & Maternal ${ }^{1}$ & Foetal ${ }^{1}$ & Foetal ${ }^{2}$ & $\begin{array}{l}\text { Placenta+ } \\
\text { Fluid }^{2}\end{array}$ & Udder ${ }^{2}$ & \multicolumn{2}{|c|}{$\begin{array}{l}\text { Ideal amino acid proffle } \\
\text { during gestation }\end{array}$} \\
\hline Lysine & 6.74 & 5.79 & 4.99 & 6.39 & 6.55 & 100 & 100 \\
\hline Methionine & 1.96 & 1.44 & 1.60 & 1.60 & 1.51 & 28 & 28 \\
\hline Meth+Cys & 3.00 & 2.77 & 2.69 & 3.20 & 3.34 & 65 & 69 \\
\hline Isoleucine & 3.67 & 2.91 & 2.50 & 3.32 & 1.57 & 65 & 55 \\
\hline Valine & 4.65 & 4.47 & 3.64 & 5.30 & 5.76 & 75 & 74 \\
\hline Leucine & 6.80 & 6.25 & 5.89 & 7.80 & 8.06 & 100 & 100 \\
\hline Histidine & 3.14 & 2.32 & 1.80 & 2.69 & 2.29 & 30 & 32 \\
\hline Phenylalanine & 3.72 & 3.39 & 2.99 & 4.35 & 4.13 & 60 & 57 \\
\hline
\end{tabular}

\subsubsection{Efficiency of amino acid utilization}

Everts et al. (1994) used an efficiency for the utilization of amino acids for protein deposition of 0.7. This was based on the efficiency factor for amino acid deposition used in growing-finishing pigs (Werkgroep TMV, 1991). Except for lysine, methionine + cysteine and threonine, there are no direct estimates of the efficiency of SID amino intake utilization for amino acid retention in gestating sows and it is not known whether these efficiencies differ among stages of gestation (NRC, 2012). Everts and Dekker (1995a) estimated an efficiency (efficiency = retained / (intake - maintenance requirement)) of lysine, methionine + cysteine and threonine of $0.46,0.34$ and 0.44 , respectively, using a diet with $17.8 \% \mathrm{CP}$ and of $0.59,0.47$ and 0.67 , respectively, with $12 \% \mathrm{CP}$ in the diet (Table 5 ). These results indicate that at the $17.8 \% \mathrm{CP}$ diet, efficiencies presumably were low because of oversupply of amino acids. It is not clear whether efficiencies were maximal at the $12 \%$ CP diet. NRC (2012) assumed that the efficiency of amino acids for protein retention in various pools is identical across pools and days of gestation. The efficiency of lysine utilization for whole body protein retention was estimated to be 0.49 from day 90 to day 114 of gestation (NRC, 2012). The efficiency of lysine for protein retention was $34.7 \%$ lower than the efficiency of lysine for maintenance ( 0.49 vs 0.75). Therefore, NRC (2012) assumed for all amino acids that the efficiency of using amino acids for protein retention was $34.7 \%$ lower than the efficiency for maintenance (Table 5).

Recently, Miller et al. (2016) estimated an efficiency of lysine utilization for protein retention in gilts of 0.47 between day 87 and 112 of gestation (17.7\% CP in the diet). Miller et al. (2017) calculated the efficiency of lysine utilization at 5 points during gestation in parity 2 and parity 3 sows. They observed a quadratic increase with day of gestation (36.1\% from day 85 to 88 and $47.4 \%$ from day 106 to 109 ; $17.7 \%$ crude protein in the diet).

In the InraPorc model Dourmad et al. (2008) used a value of 0.65 for the efficiency of lysine utilization for whole body protein, which was observed by Dourmad and Étienne (2002). The efficiencies for the other amino acids were derived from the ideal protein in the diet for gestation as derived from empirical studies (Dourmad et al., 2008). Based on SID lysine requirement, ideal protein for gestation obtained from a literature review, maintenance requirements for other amino acids and deposition of other amino acids, the efficiencies were calculated (Dourmad et al., 2008). 
Table 5 Efficiency of utilization of amino acids for whole body protein retention.

\begin{tabular}{|c|c|c|c|c|c|}
\hline & Efficiency ${ }^{1}$ & Efficiency ${ }^{2}$ & Efficiency ${ }^{3}$ & Efficiency ${ }^{4}$ & Efficiency ${ }^{6}$ \\
\hline Lysine & 0.46 & 0.59 & 0.490 & 0.47 & 0.65 \\
\hline Meth+Cys & 0.34 & 0.47 & 0.402 & & 0.56 \\
\hline Tryptophan & & & 0.467 & & 0.55 \\
\hline Isoleucine & & & 0.491 & & 0.53 \\
\hline Valine & & & 0.549 & & 0.71 \\
\hline Histidine & & & 0.636 & & 1.00 \\
\hline Phenylalanine & & & 0.542 & & 0.66 \\
\hline Phe+Tyrosine & & & 0.537 & & 0.61 \\
\hline \multicolumn{6}{|c|}{$\begin{array}{l}{ }^{1} \text { Everts and Dekker }(1995 a) \text { diet with } 17.8 \% \text { crude protein; }{ }^{2} \text { Everts and Dekker (1995a) diet with } 12.0 \% \text { crude protein; } \\
{ }^{3} \text { NRC (2012): For all amino acids the efficiency of using amino acids for protein retention was assumed to be } 34.7 \% \text { lower } \\
\left.\text { than the efficiency for maintenance; }{ }^{4} \text { Miller et al. (1996, } 1997\right) \text { between day } 106 \text { to } 109 \text { of gestation and diet with } 17.7 \% \\
\text { crude protein.; } 5 \text { Dourmad et al. (2008); }{ }^{6} \text { Calculated efficiencies of amino acids, except lysine which is based on Dourmad } \\
\text { et al. (2008). }\end{array}$} \\
\hline
\end{tabular}

Obviously, the efficiency of utilization of amino acids is higher in low protein gestation diets (about $12 \%$ crude protein) than in high protein gestation diets (about $17 \%$ crude protein) since oversupply enhances the catabolism of amino acids. As Everts and Dekker (1995a) and Dourmad et al. (2008) only measured efficiencies for three (lysine, methionine + cysteine and threonine) or one (lysine) amino acids, respectively, we decided to calculate the efficiencies of the other amino acids with the same method as used by Dourmad et al. (2008). We used the amino acid composition of maternal and foetal protein gain and of protein gain in the placenta and udder, as presented in Table 4, an efficiency of lysine of 0.65 (Dourmad et al., 2008), the ideal amino acid profile in the diet during gestation (Dourmad et al., 2008) and maintenance requirements for amino acids to calculate the efficiency of all other amino acids. The calculated efficiencies of the utilization of amino acids are presented in Table 5.

\subsection{Amino acid metabolism during lactation}

\subsubsection{Maintenance requirements}

The amino acid requirements for maintenance for lactating sows are calculated in the same way as for gestating sows. This means that amino acid requirements for maintenance include basal intestinal endogenous amino acid losses, skin and hair amino acid losses, and minimum protein turnover. Just like in gestating sows, there are limited data on the profile of intestinal amino acid losses for lactating sows. NRC (2012), therefore, assumed the amino acid profile of the intestinal endogenous losses in lactating sows to be similar to that of the growing-finishing pig (which was an average from 57 studies with ileally cannulated growing-finishing pigs reported in literature). This profile was related to ileal lysine losses determined in ad libitum fed lactating sows (0.292 g/ $\mathrm{kg}$ dry matter (DM) intake; Stein et al., 1999) to calculate the intestinal losses for each of the essential amino acids (see Table 6). The ileal intestinal endogenous losses were increased by $10 \%$ to include the contribution from large intestinal losses (NRC, 2012; Moughan, 1999). We decided to use the amino acid profile of endogenous amino acid losses of the NRC (2012). Skin and hair amino losses and amino acid losses due to minimum protein turnover were calculated as described in chapter 4.1.1. The SID amino acid losses were assumed to be used with an efficiency of $90 \%$ for maintenance (amino acid losses and minimum amino acids turnover) (Moughan, 1999). 


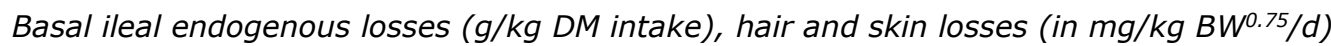
and minimum amino acid turnover (in $\mathrm{mg} / \mathrm{kg} \mathrm{BW}$. $75 / \mathrm{d}$ ) of lysine, amino acid composition of these losses ( $\mathrm{g} / 100 \mathrm{~g}$ lysine) and efficiency of amino acids for maintenance.

\begin{tabular}{|c|c|c|c|c|c|}
\hline & $\begin{array}{c}\text { Basal illeal } \\
\text { endogenous } \\
\text { losses } \\
\text { (g/kg DM } \\
\text { intake)|1 }\end{array}$ & $\begin{array}{c}\text { Basal ileal } \\
\text { endogenous } \\
\text { losses } \\
\text { (g/kg DM } \\
\text { intake)/2 }\end{array}$ & $\begin{array}{c}\text { Hair and } \\
\text { skin }(\mathrm{mg} / \mathrm{kg} \\
\left.\text { BW } \mathrm{W}^{0.75} / \mathrm{d}\right)^{3}\end{array}$ & $\begin{array}{l}\text { Minimum } \\
\text { turnover (lysine } \\
\text { in } \mathrm{mg} / \mathrm{kg} \\
\left.\mathrm{BW}^{0.75} / \mathrm{d}\right)^{4}\end{array}$ & Effficiëncy ${ }^{5}$ \\
\hline Lysine & 0.292 & 0.292 & 4.04 & 21.9 & 0.9 \\
\hline Lysine & 100 & 100 & 100 & 100 & 0.9 \\
\hline Meth+cyst & 86.9 & 78.1 & 127.9 & 44.5 & 0.9 \\
\hline Threonine & 155.5 & 145.1 & 74.4 & 55.2 & 0.9 \\
\hline Tryptophan & 44.5 & 31.8 & 20.9 & 13.1 & 0.9 \\
\hline Isoleucine & 86.3 & 91.9 & 55.8 & 54.5 & 0.9 \\
\hline Valine & 116.4 & 129.8 & 83.7 & 69.0 & 0.9 \\
\hline
\end{tabular}

${ }^{1}$ Stein et al. (1999): ad libitum fed lactating sows; ${ }^{2}$ NRC (2012): endogenous losses of lysine is based on Stein et al.

(1999); amino acid profile of the intestinal endogenous losses is an average from 57 studies with ileally cannulated growingfinishing pigs reported in literature; ${ }^{3}$ Moughan (1999): measured in growing-finishing pigs; estimated from an integumental protein loss of $94 \mathrm{mg}$ protein/ $\mathrm{BW}^{0.75} / \mathrm{d} ;{ }^{4}$ Moughan (1999): measured in growing-finishing pigs; estimated from a basal body protein loss of $325 \mathrm{mg}$ protein/ $\mathrm{BW}^{0.75} / \mathrm{d} ;{ }^{5}$ Moughan (1999)

SID lysine requirement for maintenance in lactating sows was calculated as follows:

SID Lysine requirement $(\mathrm{g} / \mathrm{d})=\left((0.292 \times 1.1 \times \mathrm{DM}\right.$ intake $\left.)+0.00404 \times \mathrm{BW}^{0.75}+0.0219 \times \mathrm{BW}^{0.75}\right) /$ 0.9 .

\subsubsection{Amino acid composition in milk}

The amino acid composition of milk has been reviewed by several authors (Everts et al., 1995; Darragh and Moughan, 1998; NRC, 2012; Hurley, 2015) (Table 7). In general, the amino acid composition of the milk in the several publications is quite comparable. Therefore, we decided to use the mean amino acid composition of milk (Table 7).

Table 7 Amino acid composition (in $\mathrm{g}$ per $100 \mathrm{gram}$ crude protein) of milk, the calculated mean and the ratio to lysine.

\begin{tabular}{|c|c|c|c|c|c|c|}
\hline & $\begin{array}{l}\text { Everts et } \\
\text { al. (1995) }\end{array}$ & $\begin{array}{c}\text { Darragh and } \\
\text { Moughan } \\
\text { (1998) }\end{array}$ & $\begin{array}{c}\text { NRC } \\
(2012)\end{array}$ & $\begin{array}{l}\text { Hurley } \\
(2015)\end{array}$ & Mean & $\begin{array}{l}\text { Ratio to } \\
\text { lysine }\end{array}$ \\
\hline Methionine & 1.95 & 1.70 & 1.89 & 1.8 & 1.84 & 25.1 \\
\hline Meth+Cys & 3.50 & 3.20 & 3.51 & 3.3 & 3.38 & 46.1 \\
\hline Isoleucine & 4.14 & 3.80 & 3.93 & 4.0 & 3.97 & 54.2 \\
\hline Valine & 5.33 & 4.70 & 4.98 & 4.9 & 4.98 & 68.0 \\
\hline Leucine & 8.63 & 8.80 & 8.41 & 8.8 & 8.66 & 118.3 \\
\hline Histidine & 3.18 & 2.40 & 3.01 & 2.9 & 2.87 & 39.2 \\
\hline Phenylalanine & 4.13 & 3.90 & 4.07 & 3.9 & 4.0 & 54.6 \\
\hline
\end{tabular}

\subsubsection{Efficiency of amino acid utilization}

The dietary SID amino acid requirement for lactating sows is estimated from daily milk protein output, amino acid composition of the milk (Table 7), maternal body protein mobilization (Appendix 1), the amino acid composition of maternal body protein (Table 4), amino acids used for maintenance (Table 6) and the efficiencies of utilizing dietary SID amino acids and amino acids from mobilized body protein for milk.

Everts et al. (1995) and NRC (2012) assumed that the efficiency of using amino acids from mobilized body protein for amino acid output in milk is identical for all essential amino acids and for protein. Everts et al. (1995) used an efficiency of utilizing body protein for amino acids in milk of 0.86 . This 
was based on research of Beyer (1986), who determined the efficiency of utilizing body protein for milk protein in lactating sows. NRC (2012), Hansen et al. (2014) and Huber et al. (2018) used an efficiency of utilizing body protein for amino acids in milk of $0.87,0.88$ and 0.87 , respectively, the same value as the energetic efficiency of utilizing body energy reserves for milk energy output. We decided to use an efficiency of 0.86 (Everts et al., 1995).

Everts et al. (1995) calculated an efficiency of utilizing dietary AID lysine for milk of 0.80 . The authors used this value also for the other essential amino acids. Based on dietary SID lysine, the efficiency is about 0.78. The NRC (2012) calculated an efficiency of dietary SID lysine utilization for milk of 0.67. This efficiency was directly calculated from a number of controlled and published studies as described in NRC (2012). As the efficiency of dietary SID lysine for milk was $10.7 \%$ lower than the efficiency of lysine for maintenance (0.67 vs 0.75), NRC (2012) assumed for all amino acids that the efficiency of using dietary SID amino acids for amino acids in milk was $10.7 \%$ lower than the efficiency for maintenance (Table 8).

Feyera and Theil (2017) used an efficiency of utilizing dietary SID lysine for milk of 0.80 . The milk yield that the NRC (2012) used to predict the efficiency of lysine was measured with the weigh-suckleweigh method which underestimates the milk yield by $20 \%$ as reviewed by Hansen et al. (2012). Therefore, Feyera and Theil (2017) used an correction factor of 1.2 resulting in an efficiency of SID dietary lysine for milk of $0.8(0.8=0.67 \times 1.2)$.

Huber et al. (2018) estimated the efficiency of dietary amino acid utilization in primiparous sows fed either a control diet ( $16.2 \%$ crude protein) or a reduced-crude protein diet supplemented with crystalline amino acids (12.7\% crude protein). They calculated the efficiency of individual dietary amino acid (AA) utilization for milk protein production ( $\mathrm{K}_{\mathrm{AA}}$ ) according to Huber et al. (2016):

$\mathrm{K}_{\mathrm{AA}}=[(\mathrm{AA}$ output in milk $-\mathrm{AA}$ mobilized from body protein $\times 0.87) /$ (dietary SID AA intake $-\mathrm{AA}$ required for maintenance / Kmaintenance) $] \times 100$

In which 0.87 is efficiency of utilizing amino acids from mobilized body protein for amino acid output in milk.

Utilization efficiency of lysine, methionine+cystine, threonine, valine and phenylalanine did not differ between sows fed the control diet or the low crude protein diet (Table 8). Utilization efficiency of isoleucine, leucine, histidine and tyrosine were greater for sows fed the low crude protein diet than for sows fed the control diet.

Recently, Gauthier et al. (2019) calculated efficiencies of utilizing amino acids for milk based on the efficiency of utilizing lysine (0.78) (Dourmad et al., 1998) and the ideal protein in the diet for lactation (Dourmad et al., 2008) (Table 8), which was based on a literature review. These efficiencies were used for both utilizing dietary amino acids for milk and utilizing amino acids from body protein mobilization for milk. Van Milgen and Dourmad (2015) determined the ideal amino acid profile in the diet for lactating sows with the NRC model (2012) (Table 8) and compared this with the ideal amino acid profile used in InraPorc (Dourmad et al., 2008). The ideal profiles used by InraPorc (Dourmad et al., 2008) and NRC (2012) are very similar. Kim et al. (2001) suggested an ideal dietary amino acid pattern for lactating sows based on the concept that different amino acid patterns are needed for tissue protein, milk protein, and dietary protein. They determined the ideal dietary amino acid profile in relation to the percentage of tissue mobilization during lactation. The ideal amino acid profile in the diet during lactation, if BW losses of the sows are about $10 \%$ during lactation, is presented in Table 8 . With increasing BW losses, the ratios of threonine, leucine and tyrosine to lysine increased. The other amino acid ratios were not influenced by the percentage of BW loss. The ideal dietary amino acid profile of Kim et al. (2001) at BW losses of the sows of about $10 \%$ during lactation, is very similar to the InraPorc (Dourmad et al., 2008) and NRC (2012) profile.

We decided to use the efficiencies of utilizing dietary amino acids for milk as calculated by Gauthier et al. (2019) because this are the maximum efficiencies based on the ideal amino acid profile in the diet during lactation. 
Table 8 Efficiency of utilization of dietary SID amino acids for milk and ideal amino acid profile in the diet during lactation.

\begin{tabular}{|c|c|c|c|c|c|c|c|c|c|}
\hline & \multirow[t]{2}{*}{ Efficiency $^{1}$} & \multirow[t]{2}{*}{ Efficiency ${ }^{2}$} & \multirow[t]{2}{*}{ Efficiency $^{3}$} & \multicolumn{2}{|c|}{ Efficiency $^{4}$} & \multirow[t]{2}{*}{$\begin{array}{l}\text { Maximum } \\
\text { Efficiency } \\
\end{array}$} & \multicolumn{3}{|c|}{$\begin{array}{l}\text { Ideal amino acid profile } \\
\text { during lactation }\end{array}$} \\
\hline & & & & $\begin{array}{l}\text { Control } \\
\text { diet }\end{array}$ & $\begin{array}{l}\text { Low } \\
\text { CP } \\
\text { diet }\end{array}$ & & $\begin{array}{c}\text { Dourmad } \\
\text { et al. } \\
(2008)^{6}\end{array}$ & $\begin{array}{c}\text { NRC } \\
(2012)^{7}\end{array}$ & $\begin{array}{c}\text { Kim et } \\
\text { al. } \\
(2001)^{8}\end{array}$ \\
\hline Lysine & 0.78 & 0.670 & 0.80 & 0.77 & 0.77 & 0.78 & 100 & 100 & 100 \\
\hline Methionine & 0.78 & 0.675 & & 0.64 & 0.53 & 0.70 & 30 & 26 & - \\
\hline Meth+Cystine & 0.78 & 0.662 & & 0.65 & 0.67 & 0.61 & 60 & 53 & - \\
\hline Threonine & 0.78 & 0.764 & & 0.65 & 0.65 & 0.74 & 66 & 63 & 60 \\
\hline Tryptophan & 0.78 & 0.674 & & 0.64 & 0.59 & 0.76 & 19 & 19 & - \\
\hline Isoleucine & 0.78 & 0.698 & & 0.55 & 0.64 & 0.74 & 60 & 56 & 59 \\
\hline Valine & 0.78 & 0.583 & & 0.54 & 0.53 & 0.66 & 85 & 85 & 77 \\
\hline Leucine & 0.78 & 0.723 & & 0.54 & 0.66 & 0.82 & 115 & 113 & 115 \\
\hline Histidine & 0.78 & 0.722 & & 0.65 & 0.70 & 0.80 & 42 & 40 & 38 \\
\hline Phenylalanine & 0.78 & 0.733 & & 0.46 & 0.45 & 0.77 & 60 & 54 & 56 \\
\hline Phe+Tyrosine & 0.78 & 0.705 & & 0.57 & 0.66 & 0.81 & 115 & 112 & 110 \\
\hline
\end{tabular}

${ }^{1}$ Everts et al. (1995); ${ }^{2}$ NRC (2012); ${ }^{3}$ Feyera and Theil (2017); ${ }^{4}$ Huber et al. (2018): control diet (16.2\% crude protein; low crude protein diet $\left(12.7 \%\right.$ crude protein); ${ }^{5}$ Gauthier et al. (2019); ${ }^{6}$ based on a literature review; ${ }^{7}$ Calculated by Van Milgen and Dourmad (2015) with the NRC model; ${ }^{8} \mathrm{Kim}$ et al. (2001) BW losses of the sows during lactation are $10 \%$.

The daily amino acid requirement is calculated with the following equation:

Daily SID amino acid requirement $(\mathrm{g} / \mathrm{d})=$ maintenance requirement amino acid + (amino acids in milk - mobilized amino acids $x$ 0.86) / efficiency of utilizing dietary amino acids for milk

In which 0.86 is efficiency of utilizing amino acids from mobilized body protein for amino acid output in milk. 


\section{Energy and amino acid requirements}

\subsection{Gestating sows}

In chapters 5.1.1., 5.1.2 and 5.1.3, the energy requirement (EW 2015/d), SID lysine requirement ( $\left.g / E W_{2015}\right)$ and ratio of other essential amino acids to lysine, respectively, during gestation of parity 1 to 5 sows are presented. The assumed BW and backfat and the calculated protein and lipid mass at mating and at farrowing of parity 1 to 5 sows and the assumed litter size and birth weight of the piglets used to predict the requirements are described in Appendix 1. Body weight, backfat, litter size and birth weight of the piglets are input factors in the model and can be changed by the user of the model.

As described in chapter 2.2, maternal gain during gestation is divided in restoration of losses in previous lactation and real growth to reach mature body weight. Real growth is assumed constant during gestation. Restoration of previous losses (protein and lipid) is either constant during gestation or a user-defined portion is additionally recovered in early gestation. The energy and SID lysine requirement and the ratio of other essential amino acids to lysine are presented for:

- no additional recovery of previous losses in early gestation which means a constant maternal daily gain during gestation;

- $60 \%$ additional recovery of previous losses in the first 42 days of gestation.

\subsubsection{Energy requirement}

In Table 9, the energy requirement ( $\left(\mathrm{WW}_{2015} / \mathrm{d}\right)$ of parity 1 to 5 sows is presented.

Table 9 Energy requirement (EW $\left.2015^{1} / d\right)$ of parity 1 to 5 sows during gestation with a constant maternal daily gain or with $60 \%$ additional recovery of previous losses in the first 42 days of gestation.

\begin{tabular}{|c|c|c|c|c|c|c|c|c|c|}
\hline \multirow[b]{2}{*}{$\begin{array}{l}\text { Additional recovery } \\
\text { maternal } \\
\text { loss in early gestation }\end{array}$} & \multirow{2}{*}{$\begin{array}{c}\text { Parity } 1 \\
\mathrm{No}^{2}\end{array}$} & \multicolumn{2}{|c|}{ Parity 2} & \multicolumn{2}{|c|}{ Parity 3} & \multicolumn{2}{|c|}{ Parity 4} & \multicolumn{2}{|c|}{ Parity 5} \\
\hline & & no & Yes $^{3}$ & no & yes & no & yes & no & yes \\
\hline \multicolumn{10}{|l|}{ Day } \\
\hline 0 & 2.26 & 2.41 & 2.98 & 2.45 & 2.98 & 2.53 & 3.00 & 2.58 & 3.04 \\
\hline 7 & 2.29 & 2.44 & 3.02 & 2.47 & 3.01 & 2.55 & 3.02 & 2.59 & 3.06 \\
\hline 14 & 2.31 & 2.46 & 3.05 & 2.49 & 3.04 & 2.57 & 3.05 & 2.61 & 3.09 \\
\hline 21 & 2.34 & 2.49 & 3.09 & 2.52 & 3.08 & 2.59 & 3.08 & 2.63 & 3.12 \\
\hline 28 & 2.38 & 2.53 & 3.15 & 2.56 & 3.13 & 2.63 & 3.13 & 2.66 & 3.16 \\
\hline 35 & 2.43 & 2.58 & 3.21 & 2.61 & 3.19 & 2.68 & 3.18 & 2.71 & 3.21 \\
\hline 42 & 2.49 & 2.64 & 2.38 & 2.67 & 2.43 & 2.73 & 2.52 & 2.76 & 2.55 \\
\hline 49 & 2.55 & 2.71 & 2.44 & 2.73 & 2.49 & 2.79 & 2.57 & 2.82 & 2.60 \\
\hline 56 & 2.62 & 2.78 & 2.50 & 2.80 & 2.55 & 2.86 & 2.63 & 2.88 & 2.65 \\
\hline 63 & 2.69 & 2.86 & 2.58 & 2.87 & 2.62 & 2.93 & 2.70 & 2.95 & 2.72 \\
\hline 70 & 2.77 & 2.94 & 2.65 & 2.95 & 2.69 & 3.00 & 2.77 & 3.02 & 2.79 \\
\hline 77 & 2.84 & 3.03 & 2.73 & 3.03 & 2.77 & 3.09 & 2.85 & 3.10 & 2.86 \\
\hline 84 & 2.92 & 3.11 & 2.81 & 3.12 & 2.84 & 3.16 & 2.92 & 3.18 & 2.93 \\
\hline 91 & 3.00 & 3.19 & 2.89 & 3.20 & 2.92 & 3.24 & 2.99 & 3.25 & 3.01 \\
\hline 98 & 3.08 & 3.28 & 2.96 & 3.28 & 2.99 & 3.32 & 3.07 & 3.33 & 3.08 \\
\hline 105 & 3.16 & 3.36 & 3.05 & 3.36 & 3.07 & 3.40 & 3.14 & 3.41 & 3.15 \\
\hline 112 & 3.24 & 3.44 & 3.12 & 3.44 & 3.14 & 3.48 & 3.21 & 3.48 & 3.22 \\
\hline Total EW 2015 (day $0-115)$ & 305 & 324 & 328 & 326 & 330 & 333 & 336 & 336 & 339 \\
\hline
\end{tabular}

${ }^{1} 1 \mathrm{EW}_{2015}=12.55 \mathrm{MJ} \mathrm{ME}\left(1 \mathrm{EW}_{2015}=8.8 \mathrm{MJ} \mathrm{NE} ; \mathrm{NE} / 0.7=\mathrm{ME}\right) ;{ }^{2}$ No: no additional recovery of previous losses in early gestation which means a constant maternal daily gain during gestation; ${ }^{3}$ Yes: $60 \%$ additional recovery of previous losses in the first 42 days of gestation

Table 9 shows that without additional recovery of previous losses in early gestation, the daily energy requirement gradually increases during gestation. Additional recovery of previous losses in the first 42 days of gestation results in a higher energy requirement at day 0 (about $0.5 \mathrm{EW}_{2015} / \mathrm{d}$ higher compared to no additional recovery), a gradual increase of the daily energy requirement from day 0 41 , a drop in energy requirement at day 42 (because of a drop in maternal protein and fat deposition) 
and then a gradual increase till day 112 of gestation. The magnitude of this drop in energy requirement depends on the percentage of additional recovery and the number of days of additional recovery. Compared to a constant maternal daily gain, the total EW supply during gestation is 3 to 4 EW higher with additional recovery of previous losses in early gestation.

The daily energy requirement of parity 1 sows is lower than the energy requirement of parity 2 to 5 sows because of the lower BW of parity 1 sows. The daily energy requirement of parity 2 and 3 sows is similar and is lower than the energy requirement of parity 4 and 5 sows.

The total energy supply in Table 9 is somewhat higher (from $10 \mathrm{EW}_{2015}$ in parity 1 sows to $2 \mathrm{EW}_{2015}$ in parity 5 sows) than the total energy supply advised by CVB (2016), mainly because of a higher maternal fat deposition during gestation and a higher litter size.

\subsubsection{Lysine requirement}

In Table 10 , the SID lysine requirement $\left(\mathrm{g} / \mathrm{EW}_{2015}\right)$ of parity 1 to 5 sows is presented.

Table 10 SID lysine requirement $\left(g / E W_{2015^{1}}\right)$ of parity 1 to 5 sows during gestation with a constant maternal daily gain or with $60 \%$ additional recovery of previous losses in the first 42 days of gestation.

\begin{tabular}{|c|c|c|c|c|c|c|c|c|c|}
\hline \multirow[b]{2}{*}{$\begin{array}{l}\text { Additional recovery } \\
\text { maternal } \\
\text { loss in early } \\
\text { gestation }\end{array}$} & \multirow{2}{*}{$\begin{array}{c}\text { Parity } 1 \\
N^{2}{ }^{2}\end{array}$} & \multicolumn{2}{|c|}{ Parity 2} & \multicolumn{2}{|c|}{ Parity 3} & \multicolumn{2}{|c|}{ Parity 4} & \multicolumn{2}{|c|}{ Parity 5} \\
\hline & & no & Yes ${ }^{3}$ & no & yes & no & yes & no & yes \\
\hline \multicolumn{10}{|l|}{ Day } \\
\hline 0 & 3.85 & 3.24 & 3.47 & 3.07 & 3.51 & 2.73 & 3.00 & 2.43 & 2.74 \\
\hline 7 & 3.83 & 3.23 & 3.45 & 3.07 & 3.49 & 2.73 & 3.00 & 2.43 & 2.74 \\
\hline 14 & 3.82 & 3.23 & 3.44 & 3.07 & 3.48 & 2.74 & 2.99 & 2.44 & 2.74 \\
\hline 21 & 3.83 & 3.25 & 3.45 & 3.10 & 3.49 & 2.77 & 3.01 & 2.48 & 2.76 \\
\hline 28 & 3.87 & 3.31 & 3.49 & 3.17 & 3.54 & 2.84 & 3.07 & 2.55 & 2.82 \\
\hline 35 & 3.96 & 3.42 & 3.57 & 3.28 & 3.62 & 2.96 & 3.16 & 2.68 & 2.92 \\
\hline 42 & 4.06 & 3.55 & 3.36 & 3.41 & 3.09 & 3.10 & 2.92 & 2.82 & 2.62 \\
\hline 49 & 4.15 & 3.67 & 3.51 & 3.54 & 3.24 & 3.23 & 3.07 & 2.96 & 2.77 \\
\hline 56 & 4.25 & 3.79 & 3.65 & 3.66 & 3.39 & 3.36 & 3.22 & 3.09 & 2.93 \\
\hline 63 & 4.36 & 3.93 & 3.81 & 3.80 & 3.56 & 3.51 & 3.39 & 3.25 & 3.10 \\
\hline 70 & 4.49 & 4.09 & 4.00 & 3.97 & 3.75 & 3.68 & 3.58 & 3.43 & 3.31 \\
\hline 77 & 4.65 & 4.27 & 4.22 & 4.16 & 3.98 & 3.88 & 3.80 & 3.64 & 3.54 \\
\hline 84 & 4.84 & 4.49 & 4.46 & 4.38 & 4.23 & 4.10 & 4.05 & 3.86 & 3.79 \\
\hline 91 & 5.04 & 4.71 & 4.72 & 4.61 & 4.49 & 4.34 & 4.31 & 4.11 & 4.06 \\
\hline 98 & 5.24 & 4.95 & 4.98 & 4.85 & 4.76 & 4.59 & 4.58 & 4.36 & 4.34 \\
\hline 105 & 5.44 & 5.17 & 5.24 & 5.08 & 5.02 & 4.82 & 4.84 & 4.60 & 4.61 \\
\hline 112 & 5.55 & 5.31 & 5.39 & 5.22 & 5.19 & 4.97 & 5.01 & 4.76 & 4.78 \\
\hline
\end{tabular}

${ }^{1} 1 \mathrm{EW}_{2015}=12.55 \mathrm{MJ} \mathrm{ME}\left(1 \mathrm{EW}_{2015}=8.8 \mathrm{MJ} \mathrm{NE} ; \mathrm{NE} / 0.7=\mathrm{ME}\right) ;{ }^{2}$ No: no additional recovery of previous losses in early gestation which means a constant maternal daily gain during gestation; ${ }^{3}$ Yes: $60 \%$ additional recovery of previous losses in the first 42 days of gestation

Table 10 shows that without additional recovery of previous losses in early gestation, the SID lysine requirement $\left(\mathrm{g} / \mathrm{EW}_{2015}\right)$ gradually increases during gestation. Additional recovery of previous losses in the first 42 days of gestation results in a higher SID lysine requirement at day 0 (about $0.3 \mathrm{~g}$ SID lysine/EW 2015 higher compared to no additional recovery), a gradual increase in SID lysine requirement ( $\mathrm{g} / \mathrm{EW}_{2015}$ ) from day 0 - 41, a drop at day 42 and then a gradual increase till day 112 of gestation. The drop in SID lysine requirement $\left(\mathrm{g} / \mathrm{EW}_{2015}\right)$ is smaller than the drop in energy requirement because the drop in protein retention is less than the drop in fat retention. The magnitude of the drop in the SID lysine requirement drops depends on the percentage of additional recovery and the number of days of additional recovery.

The SID lysine requirement ( $\mathrm{g} / \mathrm{EW}_{2015}$ ) of parity 1 sows is higher than the SID lysine requirement of parity 2 to 5 sows. The SID lysine requirement $\left(g / E W_{2015}\right)$ decreases with increasing parity of the sow. The SID lysine requirement $\left(\mathrm{g} / \mathrm{EW}_{2015}\right)$ in Table 10 (constant maternal gain) is comparable with the SID lysine requirement calculated by Everts et al. (1994). CVB (2016) recommended a dietary SID lysine content of 4.95 and $4.8 \mathrm{~g} / \mathrm{EW}_{2015}$ for parity 1 and parity 2 to 5 sows, respectively. These recommendations might be too low for parity 1 to 3 sows in the last week(s) of gestation. Based on the NRC model (2012), Trottier et al. (2015) recommends a dietary SID lysine content in the last month of gestation of $6.3,5.6,4.8,4.4$ and $4.4 \mathrm{~g} / \mathrm{EW}_{2015}$ for parity 1 to 5 sows, respectively. 


\subsubsection{Ratio of essential amino acids to lysine}

In Table 11, the ratio of SID essential amino acids to SID lysine of parity 1 to 5 sows is presented.

Table 11 Ratio (\%) of SID essential amino acids to SID lysine of parity 1 to 5 sows during gestation with a constant maternal daily gain or with $60 \%$ additional recovery of previous losses in the first 42 days of gestation.

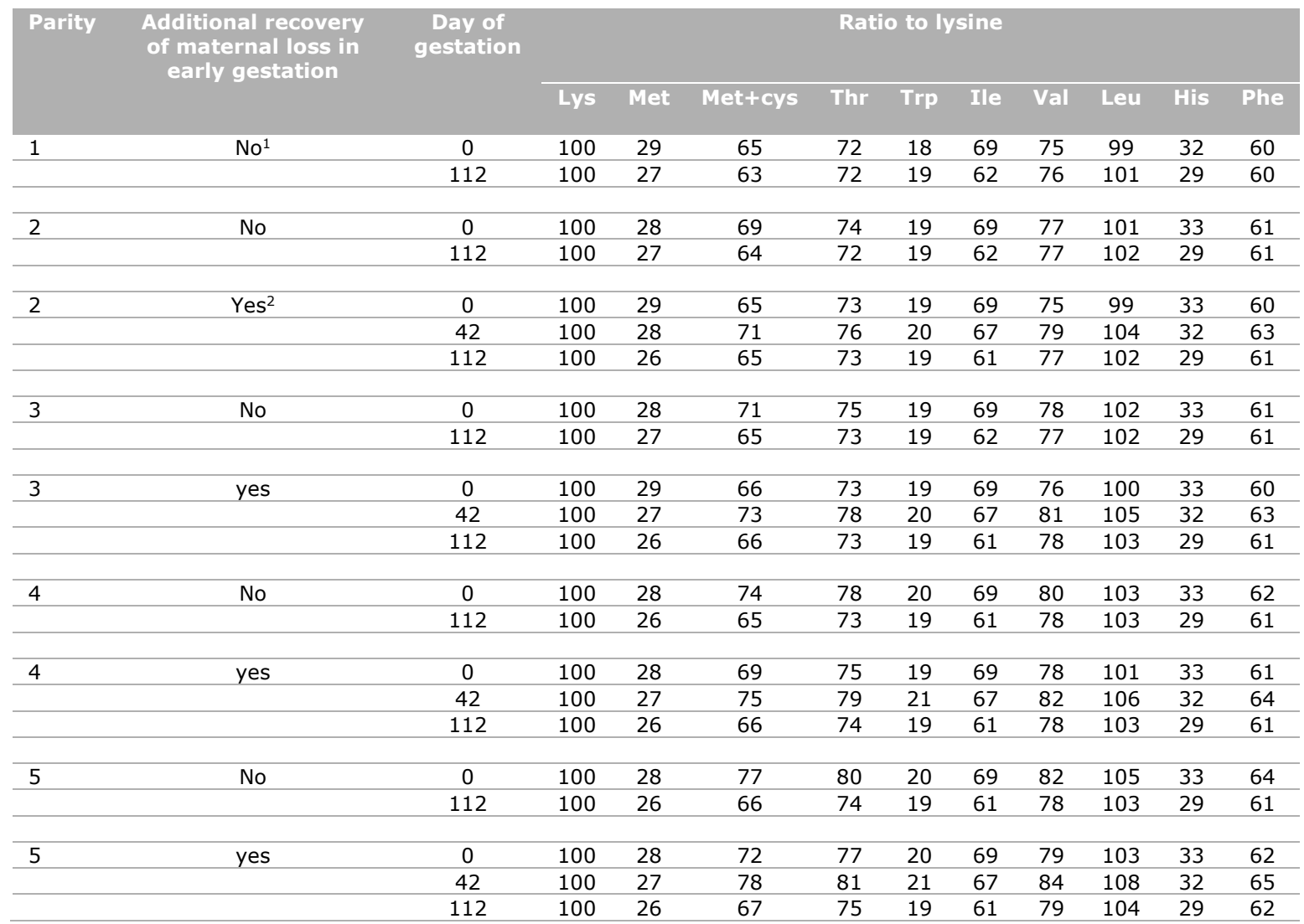

${ }^{1}$ No: no additional recovery of previous losses in early gestation which means a constant maternal daily gain during gestation; ${ }^{2}$ Yes: $60 \%$ additional recovery of previous losses in the first 42 days of gestation

Table 11 shows that without additional recovery of previous losses in early gestation the ratio of methionine + cystine, threonine, isoleucine and histidine to lysine gradually decrease during gestation. Based on NRC (2012), Trottier et al. (2015) also calculated a decrease in the ratio of these amino acids to lysine during gestation. The ratio of the other essentials amino acids to lysine are not affected by day of gestation.

Additional recovery of previous losses in the first 42 days of gestation results in a higher ratio of methionine +cystine, threonine, valine and leucine to lysine on day 42 compared to day 0 . From day 0 -41 , the ratio of these amino acids to lysine was constant. From day $42-112$ of gestation, the ratios of these amino acids to lysine gradually decreae.

The ratios of methionine + cystine, threonine, valine and leucine to lysine increase with increasing parity. The ratios of tryptophan, isoleucine, histidine and phenylalanine to lysine are not affected by parity of the sow. This is also seen by Trottier et al. (2015). CVB (2016) recommends ratios of dietary SID methionine+cystine, threonine and tryptophan to SID lysine of 65, 77 and 17\%, respectively. Based on the results in Table 11, we advise ratios of dietary SID methionine+cystine, threonine, tryptophan, isoleucine, valine, leucine, histidine and phenylalanine to SID lysine of $68,75,19,65,78$, 102,32 and 61, respectively.

\subsubsection{Influence of sow characteristics on requirements}

Body weight, backfat, litter size and birth weight of the piglets are input factors in the model and can be changed by the user of the model. The effect of BW and backfat at mating and at farrowing of a parity 1 sow on the energy requirement $\left(E_{2} 2015 / d\right)$ and SID lysine requirement ( $\left.g / E W_{2015}\right)$ during gestation is presented in Table 12 . 
Table 12 Effect of body weight (BW) and backfat (BF) at mating and at farrowing of a parity 1 sow on the energy requirement ( $\left.E W_{2015} / d\right)$ and SID lysine requirement ( $\left.g / E W_{2015}\right)$ at day 0 , 42,84 and 112 of gestation.

\begin{tabular}{|c|c|c|c|c|c|c|}
\hline \multirow[b]{2}{*}{ Day } & \multicolumn{2}{|c|}{$\begin{array}{c}\text { BW at mating } / \text { farrowing }^{1} \\
140 / 195 \mathrm{~kg} \\
\text { BF at mating } / \text { farrowing }^{13 / 17 \mathrm{~mm}}\end{array}$} & \multicolumn{2}{|c|}{$\begin{array}{c}\text { BW at mating / farrowing } \\
160 / 215 \mathrm{~kg} \\
\text { BF at mating } / \text { farrowing } \\
13 / 17 \mathrm{~mm}\end{array}$} & \multicolumn{2}{|c|}{$\begin{array}{c}\text { BW at mating / farrowing } \\
160 / 215 \mathrm{~kg} \\
\text { BF at mating } / \text { farrowing } \\
12 / 15 \mathrm{~mm}\end{array}$} \\
\hline & $\mathrm{EW}_{2015} / \mathrm{d}$ & $\begin{array}{l}\text { SID lysine } \\
\left(\mathrm{g} / \mathrm{EW}_{2015}\right)\end{array}$ & $\mathrm{EW}_{2015} / \mathrm{d}$ & $\begin{array}{l}\text { SID lysine } \\
\left(\mathrm{g} / \mathrm{EW}_{2015}\right)\end{array}$ & $\mathrm{EW}_{2015} / \mathrm{d}$ & $\begin{array}{l}\text { SID lysine } \\
\left(\mathrm{g} / \mathrm{EW}_{2015}\right)\end{array}$ \\
\hline 0 & 2.26 & 3.85 & 2.41 & 3.70 & 2.37 & 3.91 \\
\hline 42 & 2.49 & 4.06 & 2.64 & 3.91 & 2.59 & 4.11 \\
\hline 84 & 2.92 & 4.84 & 3.06 & 4.68 & 3.02 & 4.86 \\
\hline 112 & 3.24 & 5.55 & 3.37 & 5.38 & 3.33 & 5.55 \\
\hline
\end{tabular}

${ }^{1} \mathrm{BW}$ at farrowing is excluding uterine contents

A higher BW at mating (160 vs $140 \mathrm{~kg}$ ) with the same maternal gain during gestation (55 kg) and the same backfat development results in a higher daily energy requirement during gestation of about 0.15 $\mathrm{EW}_{2015} / \mathrm{d}$ and a lower SID lysine requirement of about $0.15 \mathrm{~g} / \mathrm{EW}_{2015}$. The SID lysine requirement ( $\mathrm{g} / \mathrm{EW}_{2015}$ ) is lower because of the higher energy intake.

A higher BW at mating (160 vs $140 \mathrm{~kg}$ ) in combination with $1 \mathrm{~mm}$ less backfat at mating (12 vs 13 $\mathrm{mm}$ ) and $2 \mathrm{~mm}$ less backfat at farrowing (15 vs $17 \mathrm{~mm}$ ) results in a higher daily energy requirement of about $0.10 \mathrm{EW}_{2015} / \mathrm{d}$ and a higher SID lysine requirement in the first half of gestation of about 0.05 $\mathrm{g} / \mathrm{EW}_{2015}$. The SID lysine requirement $\left(\mathrm{g} / \mathrm{EW}_{2015}\right)$ is higher because of a higher maternal protein deposition ( $8.2 \mathrm{~kg}$ vs $7.8 \mathrm{~kg}$ ) and a lower maternal fat deposition (16.5 vs $18.2 \mathrm{~kg}$ ) during gestation.

\subsubsection{Updated recommendations}

In this chapter, summarizing tables with the energy requirement $\left(E W_{2015} / d\right)$, SID lysine requirement (g/EW 2015) and ratio of other essential amino acids to lysine during gestation of parity 1 to 5 sows, assuming a constant maternal daily gain, are presented. The requirements assuming additional recovery of previous losses in early gestation are not summarized as the portion and number of days of additional recovery are user-defined. The requirements assuming $60 \%$ additional recovery of previous losses in the first 42 days of gestation are presented in Tables 9, 10 and 11.

In Table 13, the energy requirement $\left(\mathrm{EW}_{2015} / \mathrm{d}\right)$ during gestation of parity 1 to 5 sows, assuming a constant maternal daily gain during gestation, is presented.

Table 13 Energy requirement (EW $2015 / d)$ of parity 1 to 5 sows with a constant maternal daily gain during gestation.

\begin{tabular}{lrrrrr} 
Day & Parity 1 & Parity 2 & Parity 3 & Parity 4 & Parity 5 \\
$0-27$ & 2.30 & 2.45 & 2.48 & 2.56 & 2.60 \\
\hline $29-55$ & 2.46 & 2.62 & 2.64 & 2.97 & 2.99 \\
\hline $56-83$ & 2.73 & 2.90 & 2.91 & 3.20 & 3.22 \\
\hline $84-97$ & 2.96 & 3.15 & 3.16 & 3.36 & 3.37 \\
\hline $98-112$ & 3.12 & 3.32 & 3.32 & & \\
\hline
\end{tabular}

The daily energy requirement of parity 1 sows is lower than the energy requirement of parity 2 to 5 sows because of the lower BW of parity 1 sows. The daily energy requirement of parity 2 and 3 sows is similar and is lower than the energy requirement of parity 4 and 5 sows.

In Table 14, the SID lysine requirement ( $\left.\mathrm{g} / \mathrm{EW}_{2015}\right)$ during gestation of parity 1 to 5 sows, assuming a constant maternal daily gain during gestation, is presented.

Table 14 SID lysine requirement ( $g / E W_{2015}$ ) of parity 1 to 5 sows with a constant maternal daily gain during gestation.

\begin{tabular}{lrrrrr} 
Day & Parity 1 & Parity 2 & Parity 3 & Parity 4 & Parity 5 \\
$0-27$ & 3.83 & 3.24 & 3.08 & 2.74 & 3.03 \\
\hline $29-55$ & 4.01 & 3.49 & 3.35 & 3.61 & 3.75 \\
\hline $56-83$ & 4.45 & 4.02 & 3.90 & 4.22 & 3.99 \\
\hline $84-97$ & 4.94 & 4.60 & 4.50 & 4.71 & 4.48 \\
\hline $98-112$ & 5.34 & 5.06 & 4.97 & \\
\hline
\end{tabular}


The SID lysine requirement $\left(\mathrm{g} / \mathrm{EW}_{2015}\right)$ of parity 1 sows is higher than the SID lysine requirement of parity 2 to 5 sows. The SID lysine requirement $\left(\mathrm{g} / \mathrm{EW}_{2015}\right)$ decreases with increasing parity of the sow.

In Table 15, the recommended levels of other essential amino acids (in $\mathrm{g} / \mathrm{EW} 2015$ ) and the ratio to lysine during gestation are presented. The recommended SID lysine level is based on the SID lysine requirement of a parity 3 sow at day 98 of gestation. This recommendation might be too low for parity 1 and 2 sows in the last weeks of gestation.

Table 15 Recommended levels of SID essential amino acids $\left(g / E W_{2015}\right)^{1}$ and the ratio to SID lysine (\%; between brackets) in diets for gestating sows

\begin{tabular}{lc} 
Amino acid & Level of SID amino acids and ratio to lysine \\
\begin{tabular}{lc} 
Lysine & $4.85(100)$ \\
\hline Methionine+cystine ${ }^{2}$ & $3.30(68)$ \\
\hline Threonine & $3.64(75)$ \\
\hline Tryptophan & $0.92(19)$ \\
\hline Isoleucine & $3.15(65)$ \\
\hline Valine & $3.78(78)$ \\
\hline Leucine & $4.95(102)$ \\
\hline Histidine & $1.55(32)$ \\
\hline Phenylalanine & $2.96(61)$ \\
\hline 1 These levels might be too low for parity 1 and 2 sows in the last weeks of gestation.
\end{tabular} \\
\hline 2 A minimum ratio of methionine to methionine+cystine of 55\% is advised.
\end{tabular}

\subsection{Lactating sows}

In chapters 5.2.1., 5.2.2 and 5.2.3, the energy requirement ( $\left.E W_{2015} / d\right)$, SID lysine requirement ( $\left.\mathrm{g} / \mathrm{EW}_{2015}\right)$ and ratio of other essential amino acids to lysine, respectively, during lactation of parity 1 to 5 sows are presented. The assumed losses of body weight, back fat, protein and fat during lactation are described in chapter 2.8 and Appendix 1. Body weight, backfat, number of suckling piglets, birth weight of the piglets and litter gain of the piglets are input factors in the model and can be changed by the user of the model. The energy and SID requirement and the ratio of other essential amino acids to lysine are presented assuming litter gains of 2.5 and $3.0 \mathrm{~kg} / \mathrm{d}$. The milk prediction is predicted from weekly daily gain of the suckling piglets (Tables $16 a, 17 a$ and $18 a$ ) or with milk production curves from Hansen et al. (2012) (Tables 16b, 17b and 18b).

\subsubsection{Energy requirement}

In Tables $16 a$ and $16 \mathrm{~b}$, the energy requirement $\left(\mathrm{EW}_{2015} / \mathrm{d}\right)$ of parity 1 to 5 sows during lactation is presented.

Table 16a Energy requirement $\left(E W_{2015^{1}} / d\right)$ of parity 1 to 5 sows per week of lactation (milk production predicted from weekly daily gain of the suckling piglets).

\begin{tabular}{lcccccccccc} 
& \multicolumn{2}{c}{ Parity 1} & Parity 2 & Parity 3 & Parity 4 & Parity 5 \\
$\begin{array}{l}\text { Litter gain }(\mathrm{kg} / \mathrm{d}) \\
\text { Week }\end{array}$ & 2.5 & 3.0 & 2.5 & 3.0 & 2.5 & 3.0 & 2.5 & 3.0 & 2.5 & 3.0 \\
\hline 1 & & & & & & & & & & \\
\hline 2 & 4.40 & 5.18 & 4.84 & 5.61 & 5.17 & 5.94 & 5.27 & 6.04 & 5.56 & 6.33 \\
\hline 3 & 5.97 & 7.11 & 6.39 & 7.52 & 6.73 & 7.86 & 6.84 & 7.96 & 7.14 & 8.26 \\
\hline 4 & 6.46 & 7.69 & 6.89 & 8.10 & 7.23 & 8.45 & 7.34 & 8.55 & 7.65 & 8.86 \\
\hline mean & 6.22 & 7.36 & 6.66 & 7.79 & 7.02 & 8.14 & 7.12 & 8.25 & 7.44 & 8.57 \\
\hline
\end{tabular}

${ }^{1} 1 \mathrm{EW}=12.55 \mathrm{MJ} \mathrm{ME}(1 \mathrm{EW}=8.8 \mathrm{MJ} \mathrm{NE} ; \mathrm{NE} / 0.7=\mathrm{ME})$; 
Table 16b Energy requirement (EW $2015^{1} / d$ ) of parity 1 to 5 sows per week of lactation (milk production predicted with the milk production curves from Hansen et al. (2012))

\begin{tabular}{lcccccccccc} 
& \multicolumn{2}{c}{ Parity 1} & \multicolumn{2}{c}{ Parity 2} & \multicolumn{2}{c}{ Parity 3} & Parity 4 & \multicolumn{2}{c}{ Parity 5} \\
Litter gain $(\mathrm{kg} / \mathrm{d})$ & 2.5 & 3.0 & 2.5 & 3.0 & 2.5 & 3.0 & 2.5 & 3.0 & 2.5 & 3.0 \\
\hline Week & & & & & & & & & & \\
\hline 1 & 4.28 & 4.28 & 4.90 & 4.90 & 5.22 & 5.23 & 5.33 & 5.33 & 5.62 & 5.62 \\
\hline 2 & 6.19 & 6.61 & 6.97 & 7.42 & 7.31 & 7.76 & 7.42 & 7.86 & 7.72 & 8.16 \\
\hline 3 & 6.30 & 6.99 & 7.01 & 7.73 & 7.35 & 8.08 & 7.46 & 8.18 & 7.77 & 8.49 \\
\hline 4 & 5.74 & 6.56 & 6.29 & 7.15 & 6.65 & 7.51 & 6.76 & 7.61 & 7.08 & 7.93 \\
\hline mean & 5.63 & 6.11 & 6.29 & 6.80 & 6.64 & 7.14 & 6.74 & 7.25 & 7.05 & 7.55 \\
\hline
\end{tabular}

${ }^{1} 1 \mathrm{EW}=12.55 \mathrm{MJ} \mathrm{ME}(1 \mathrm{EW}=8.8 \mathrm{MJ} \mathrm{NE} ; \mathrm{NE} / 0.7=\mathrm{ME})$;

Tables $16 \mathrm{a}$ and $16 \mathrm{~b}$ show that the energy requirement of lactating sows increases from week 1 to 3 of lactation and decreases in week 4 of lactation. Moreover, the energy requirement increases with increasing litter gain and parity of the sow. At a litter gain of $2.5 \mathrm{~kg} / \mathrm{d}$, the predicted mean energy requirements of the sows based on milk production curves or on weekly daily gain of the suckling piglets are very similar. At a litter gain of $3.0 \mathrm{~kg} / \mathrm{d}$, however, the predicted mean energy requirement based on weekly daily gain of the suckling piglets is higher $(0.73$ and $0.45 \mathrm{EW} / \mathrm{d}$ in parity 1 and parity 2 to 5 sows, respectively) than the predicted mean energy requirement based on milk production curves. A litter gain of $3.0 \mathrm{~kg} / \mathrm{d}$ is $20 \%$ higher than a litter gain of $2.5 \mathrm{~kg} / \mathrm{d}$. We expected that a $20 \%$ increase in daily litter gain would result in a higher milk production/daily energy requirement of about $20 \%$. The $20 \%$ increase in daily litter gain, however, resulted in an increase in energy requirement of about $18 \%$ based on weekly daily gain of the suckling piglets and of about $8 \%$ based on the milk production curves of Hansen et al. (2012). Therefore, we prefer to predict the milk production and daily energy requirement based on weekly daily gain of the suckling piglets.

\subsubsection{Lysine requirement}

In Tables $17 \mathrm{a}$ and $17 \mathrm{~b}$, the SID lysine requirement $\left(\mathrm{g} / \mathrm{EW}_{2015}\right)$ of parity 1 to 5 sows during lactation is presented.

Table 17a SID lysine requirement $\left(\mathrm{g} / E W_{2015^{1}}\right)$ of parity 1 to 5 sows per week of lactation (milk production predicted from weekly daily gain of the suckling piglets)

\begin{tabular}{lcccccccccc} 
& \multicolumn{2}{c}{ Parity 1} & Parity 2 & Parity 3 & Parity 4 & Parity 5 \\
$\begin{array}{l}\text { Litter gain }(\mathrm{kg} / \mathrm{d}) \\
\text { Week }\end{array}$ & 2.5 & 3.0 & 2.5 & 3.0 & 2.5 & 3.0 & 2.5 & 3.0 & 2.5 & 3.0 \\
\hline 1 & & & & & & & & & & \\
\hline 2 & 8.52 & 8.70 & 7.78 & 8.04 & 7.76 & 8.01 & 7.62 & 7.89 & 7.66 & 7.91 \\
\hline 3 & 8.16 & 8.29 & 7.61 & 7.81 & 7.59 & 7.79 & 7.49 & 7.70 & 7.52 & 7.71 \\
\hline 4 & 8.35 & 8.46 & 7.82 & 8.01 & 7.79 & 7.97 & 7.69 & 7.88 & 7.70 & 7.88 \\
\hline mean & 8.59 & 8.69 & 8.03 & 8.21 & 7.98 & 8.15 & 7.88 & 8.06 & 7.87 & 8.05 \\
\hline
\end{tabular}

${ }^{1} 1 \mathrm{EW}=12.55 \mathrm{MJ} \mathrm{ME}(1 \mathrm{EW}=8.8 \mathrm{MJ} \mathrm{NE} ; \mathrm{NE} / 0.7=\mathrm{ME})$;

Table $17 \boldsymbol{b} S I D$ lysine requirement $\left(\mathrm{g} / E W_{2015^{1}}\right)$ of parity 1 to 5 sows per week of lactation (milk production predicted with the milk production curves from Hansen et al. (2012))

\begin{tabular}{lcccccccccc} 
& \multicolumn{2}{c}{ Parity 1} & \multicolumn{2}{c}{ Parity 2 } & Parity 3 & Parity 4 & \multicolumn{2}{c}{ Parity 5} \\
$\begin{array}{l}\text { Litter gain }(\mathrm{kg} / \mathrm{d}) \\
\text { Week }\end{array}$ & 2.5 & 3.0 & 2.5 & 3.0 & 2.5 & 3.0 & 2.5 & 3.0 & 2.5 & 3.0 \\
\hline 1 & & & & & & & & & & \\
\hline 2 & 8.49 & 8.49 & 7.80 & 7.80 & 7.78 & 7.78 & 7.65 & 7.65 & 7.68 & 7.68 \\
\hline 3 & 8.19 & 8.24 & 7.72 & 7.80 & 7.70 & 7.77 & 7.61 & 7.68 & 7.63 & 7.70 \\
\hline 4 & 8.33 & 8.40 & 7.84 & 7.96 & 7.81 & 7.92 & 7.71 & 7.83 & 7.72 & 7.83 \\
\hline mean & 8.54 & 8.63 & 7.96 & 8.12 & 7.91 & 8.06 & 7.80 & 7.96 & 7.80 & 7.95 \\
\hline
\end{tabular}

${ }^{1} 1 \mathrm{EW}=12.55 \mathrm{MJ} \mathrm{ME}(1 \mathrm{EW}=8.8 \mathrm{MJ} \mathrm{NE} ; \mathrm{NE} / 0.7=\mathrm{ME})$;

Tables $17 \mathrm{a}$ and $17 \mathrm{~b}$ show that the SID lysine requirement $\left(\mathrm{g} / \mathrm{EW}_{2015}\right)$ of lactating sows decreases from week 1 to week 2 of lactation and then gradually increases from week 2 to week 4 of lactation. In week 4, the SID lysine requirement $\left(\mathrm{g} / \mathrm{EW}_{2015}\right)$ is highest. The SID lysine requirement $\left(\mathrm{g} / \mathrm{EW}_{2015}\right)$ increases with increasing litter gain. The SID lysine requirement ( $\left.g / E W_{2015}\right)$ is highest in parity 1 sows whereas it is very similar in parity 2 to 5 sows. The SID lysine requirements ( $\mathrm{g} / \mathrm{EW}_{2015}$ ) based on milk production curves or on weekly daily gain of the suckling piglets are very similar. 
CVB (2016) recommends a dietary SID lysine content of $6.6 \mathrm{~g} / \mathrm{EW}_{2015}$, which is much lower than the recommendations in Tables $17 \mathrm{a}$ and $17 \mathrm{~b}$. The reasons for this are:

- $\quad$ The CVB recommendations (2016) are based on the assumption that there is no mobilisation of body protein and fat, whereas we assume mobilisation of body protein and fat as described in Appendix 1. Because more body fat than body protein is mobilized during lactation, the daily dietary energy requirement will decrease more than the daily dietary SID lysine requirement resulting in an increase in dietary SID lysine requirement (in g/EW2015) of 0.8 to $1.0 \mathrm{~g} / \mathrm{EW}$ compared with no mobilisation of body protein and body fat.

- The CVB (2016) assume a litter gain of $2.25 \mathrm{~kg} / \mathrm{d}$, whereas we assume a litter gain of 2.5 and $3.0 \mathrm{~kg} / \mathrm{d}$.

- $\quad$ Based on Everts et al. (1995), CVB (2016) used an efficiency of utilizing dietary SID lysine for milk of 0.83 , whereas we used an efficiency of 0.78 . An efficiency of 0.83 results in an reduction of the dietary SID lysine requirement (in g/EW 2015 ) of about $0.5 \mathrm{~g} / \mathrm{EW}_{2015}$ compared to an efficiency of 0.78 .

Based on the NRC model (2012), Trottier et al. (2015) recommends a dietary SID lysine content during lactation of 8.0 and $7.7 \mathrm{~g} / \mathrm{EW}$ for parity 1 and parity $2+$ sows with a litter gain of $3.0 \mathrm{~kg} / \mathrm{d}$, respectively, which is 0.5 (for parity 1 sows) to 0.2 (for parity 5 sows) lower than the recommendations in Table $17 \mathrm{a}$ and $17 \mathrm{~b}$.

Feyera and Theil (2017) predicted the SID lysine requirement ( $\mathrm{g} / \mathrm{d}$ ) and the SID lysine : ME ratio during early and peak lactation using a factorial approach. The SID lysine requirement (64 g/d) and SID lysine : ME ratio (0.6) at peak lactation of sows with an intermediate milk yield were very comparable with our results (SID lysine requirement is $67 \mathrm{~g} / \mathrm{d}$ and SID lysine : ME ratio is 0.63 at peak lactation in a parity 4 sow).
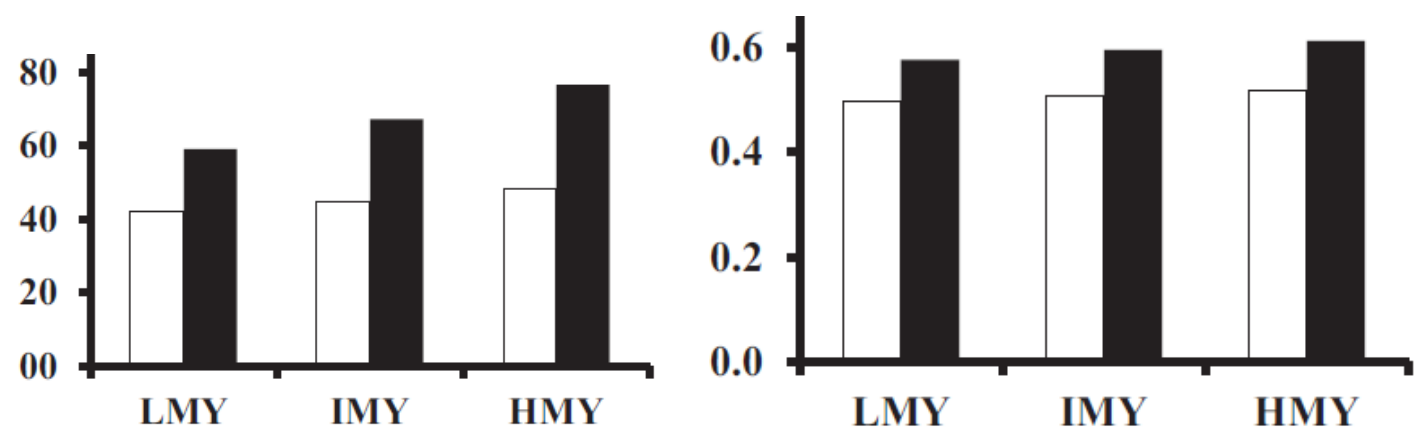

Figure 7 Impact of 3 levels of milk yield on SID lysine requirement ( $\mathrm{g} / \mathrm{d}$ ) (left Figure) and SID lysine: ME ratio (right figure) at early (white bar) and at peak (black bar) lactation. Low milk yield (LMY; characterized by 12 piglets/litter and $2.4 \mathrm{~kg} / \mathrm{d}$ litter gain); intermediate milk yield (IMY; characterized by 13 piglets/litter and $2.8 \mathrm{~kg} / \mathrm{d}$ litter gain); high milk yield (HMY; characterized by 14 piglets/litter and $3.2 \mathrm{~kg} / \mathrm{d}$ litter gain) (Feyera and Theil (2017)

\subsubsection{Ratio of essential amino acids to lysine}

In Table 18, the ratio of SID essential amino acids to SID lysine of parity 1 to 5 sows during lacctation is presented.

Table 18 Milk yield ( $\mathrm{kg} / \mathrm{d}$ ) and ratio (\%) of SID essential amino acids to SID lysine of parity 1 to 5 lactating sows (litter gain parity 1 sows: $2.5 \mathrm{~kg} / \mathrm{d}$; parity $2-5$ sows: $3.0 \mathrm{~kg} / \mathrm{d}$ ).

\begin{tabular}{|c|c|c|c|c|c|c|c|c|c|c|c|c|c|}
\hline Parity & Week & $\begin{array}{l}\text { Milk } \\
\text { yield }\end{array}$ & \multicolumn{11}{|c|}{ Ratio to lysine } \\
\hline 1 & $1-4$ & 10.5 & 100 & 27 & 60 & 63 & 20 & 58 & 82 & 115 & 38 & 56 & - \\
\hline 3 & $1-4$ & 12.6 & 100 & 28 & 60 & 63 & 19 & 58 & 82 & 114 & 38 & 56 & - \\
\hline 4 & $1-4$ & 12.6 & 100 & 28 & 60 & 63 & 19 & 58 & 82 & 114 & 38 & 56 & - \\
\hline 5 & $1-4$ & 12.6 & 100 & 28 & 60 & 63 & 19 & 58 & 82 & 113 & 39 & 56 & - \\
\hline
\end{tabular}

The ratio of SID essential amino acids to SID lysine did not differ between week of lactation and therefore the mean of week 1- 4 of lactation is presented. Moreover, the ratios are not affected by parity or by the method op predicting the milk production (milk production curves or weekly daily gain of the suckling piglets). The ratio of SID threonine to SID lysine of $63 \%$ is comparable with the ratio 
recommended by NRC (2012) but lower than the recommended ratios of 65\% (Greiner et al., 2019), $66 \%$ (Dourmad et al., 2008) and 67\% CVB (2016). The ratio of SID valine to SID lysine of $82 \%$ in Table 18 is lower than the ratio of $85 \%$ recommended by Dourmad et al. (2008) and NRC (2012). The other ratios in Table 18 are very comparable with those used by Dourmad et al. (2008).

Strathe et al. (2016) conducted a study with five hundred fifty-eight sows (parity 1 to 4 ) to investigate the effect of increasing the dietary valine-to-lysine ratio for lactating sows weaning more than 12 piglets. Diets had a total dietary valine to lysine ratio of $0.84,0.86,0.88,0.90,0.95$, or $0.99: 1$. The results of their study showed no effect of increasing the total dietary valine to lysine ratio above $0.84: 1$ (SID valine to SID lysine of $0.80: 1$ ) on litter growth and sow metabolism. Concentrations of urea in plasma and milk were similar in all 6 groups, which emphasized that increasing the dietary SID valine to SID lysine ratio above $80 \%$ did not give a more ideal amino acid composition of the dietary protein for the lactating sow. Thus, a ratio of SID valine to SID lysine of $82 \%$ as we calculated seems to be sufficient for lactating sows.

Based on the results in Table 18, we advise ratios of dietary SID methionine+cystine, threonine, tryptophan, isoleucine, valine, leucine, histidine and phenylalanine to SID lysine of $60,63,19,58,82$, 114,38 and 56, respectively.

\subsubsection{Updated recommendations}

In this chapter, summarizing tables with the energy requirement (EW2015/d), SID lysine requirement $\left(\mathrm{g} / \mathrm{EW}_{2015}\right)$ and ratio of other essential amino acids to lysine of parity 1 to 5 lactating sows, assuming a daily litter gain of $2.5 \mathrm{~kg} / \mathrm{d}$ in parity 1 sows and $3.0 \mathrm{~kg} / \mathrm{d}$ in parity $2-5$ sows, are presented. The daily energy and lysine requirements are based on milk production predicted from weekly daily gain of the suckling piglets.

In Table 19, the energy requirement $\left(\mathrm{EW}_{2015} / \mathrm{d}\right)$ per week of lactation is presented.

Table 19 Energy requirement $\left(E W_{2015} / d\right)$ of parity 1 to 5 sows per week of lactation (milk production predicted from weekly daily gain of the suckling piglets; litter gain parity 1 sows: $2.5 \mathrm{~kg} / \mathrm{d}$; litter gain parity $2-5$ sows: $3.0 \mathrm{~kg} / \mathrm{d}$ ).

\begin{tabular}{lrrrrr} 
Week & Parity 1 & Parity 2 & Parity 3 & Parity 4 & Parity 5 \\
1 & 4.40 & 5.61 & 5.94 & 6.04 & 7.96 \\
\hline 2 & 5.97 & 7.52 & 7.86 & 8.55 & 8.86 \\
\hline 3 & 6.46 & 8.10 & 8.45 & 8.25 & 8.57 \\
\hline mean & 6.22 & 7.79 & 8.14 & 7.70 & 8.00 \\
\hline
\end{tabular}

The energy requirement of lactating sows increases from week 1 to 3 of lactation and decreases in week 4 of lactation. The energy requirement increases with increasing parity of the sow.

In Table 20, the SID lysine requirement ( $\left.\mathrm{g} / \mathrm{EW}_{2015}\right)$ per week of lactation is presented.

Table 20 SID lysine requirement (g/EW2015) of parity 1 to 5 sows per week of lactation (milk production predicted from weekly daily gain of the suckling piglets; litter gain parity 1 sows: $2.5 \mathrm{~kg} / \mathrm{d}$; litter gain parity $2-5$ sows: $3.0 \mathrm{~kg} / \mathrm{d}$ )

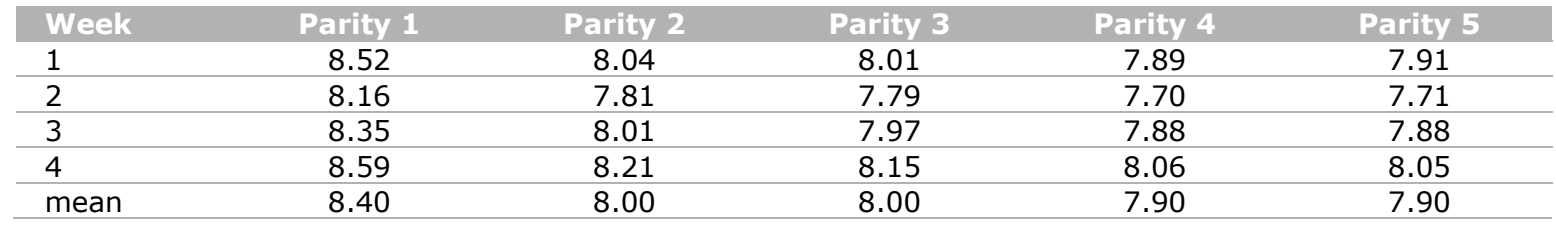

In Table 21, the recommended levels of other essential amino acids (in $\mathrm{g} / \mathrm{EW}_{2015}$ ) and the ratio to lysine during lactation are presented. The recommended SID lysine level is based on the mean SID lysine requirement of a parity 2 and 3 sow. This recommendation might be too low for parity 1 sows. 
Table 21 Recommended levels of SID essential amino acids ( $\left.g / E W_{2015}\right)^{1}$ and the ratio to SID lysine (\%; between brackets) in diets for lactating sows

\begin{tabular}{lc} 
Amino acid & Level of SID amino acids and ratio to lysine \\
Lysine & $8.00(100)$ \\
\hline Methionine+cystine ${ }^{2}$ & $4.80(60)$ \\
\hline Threonine & $5.04(63)$ \\
\hline Tryptophan & $1.52(19)$ \\
\hline Isoleucine & $4.64(58)$ \\
\hline Valine & $6.56(82)$ \\
\hline Leucine & $9.12(114)$ \\
\hline Histidine & $3.04(38)$ \\
\hline Phenylalanine & $4.48(56)$
\end{tabular}

1 These levels might be too low for parity 1 sows.

${ }^{2}$ A minimum ratio of methionine to methionine+cystine of $55 \%$ is advised. 


\section{Effects of arginine supplementation}

Some amino acids like arginine have specific effects. Arginine is a semi or conditionally essential amino acid. It is a precursor of biologically active molecules, such as nitric oxide and polyamines, which favour embryonic and foetal growth and development (Wu, 2010). Palencia et al. (2018) reviewed the effects of dietary arginine supplementation for pregnant sows on foetal development (Table 22). Arginine supplementation levels varied in the selected papers from $0.4 \%$ to $1.3 \%$; the most tested level ( $47 \%$ of trials) was $1 \%$.

Table 22 Effect of arginine supplementation during gestation in sows (Palencia et al., 2018).

\begin{tabular}{|lllllll|}
\hline Reference & A & B & C & D & E & F \\
\hline Mateo et al. (2007) & NE & NS & 2.3 & NS & 24.18 & + \\
\hline Mateo et al. (2008) & NE & NE & NE & NE & NS & IND \\
\hline Bérard and Bee (2010) & NS & NS & 3.7 & NS & 32.7 & + \\
\hline Li et al. (2010). Trial 1 & NS & -0.5 & -0.4 & NE & 7.3 & - \\
\hline Li et al. (2010). Trial 2 & NS & -3.1 & -3.1 & NE & -50.9 & - \\
\hline Gao et al. (2012) & 16.11 & 1.3 & 1.1 & 8.28 & 10.75 & + \\
\hline Liu et al. (2012) & NE & NS & NS & NS & 15.16 & + \\
\hline Novak et al. (2012) & NS & NE & NS & NE & NS & IND \\
\hline Wu et al. (2012) & NE & NS & NS & NS & 10.96 & + \\
\hline Che et al. (2013). Trial 1 & NE & NS & NS & NS & NS & IND \\
\hline Che et al. (2013). Trial 2 & NE & NS & 1.62 & NS & NS & + \\
\hline Li et al. (2014). Trial 1 & 33.98 & NS & 2.2 & NE & NS & + \\
\hline Li et al. (2014). Trial 2 & 20.97 & NS & 1.7 & NE & NS & + \\
\hline Quesnel et al. (2014) & NE & NS & NS & -20.1 & -23.3 & - \\
\hline Garbossa et al. (2015) & NS & NS & NS & NE & NS & IND \\
\hline Li et al. (2015). Trial 1 & NE & 1.16 & 1.24 & 8.25 & 8.03 & + \\
\hline Li et al. (2015). Trial 2 & NE & NS & NS & NS & NS & IND \\
\hline A & & & & & \\
\hline
\end{tabular}

A. Placenta weight (\% of increase compared to the control group); B. number of foetuses or total piglets born compared to the control; C. number of viable foetuses or piglets born alive compared to the control; D. difference in per cent in the weight of foetuses or total piglets born compared to the control; E. difference in per cent in the weight of viable foetuses or piglets born alive compared to the control; F. benefits of using arginine.

NS, not significant; NE, not evaluated; IND, indifferent.

Arginine was supplemented in the first third of pregnancy in $47 \%$ of tests, including both primiparous and multiparous sows. These studies showed positive results for embryo survival and foetal development, evidenced by the increase in placental weight and the number and weight of piglets born alive (Palencia et al., 2018). Of all evaluated studies, 53\% showed benefits of arginine supplementation on foetal development (Palencia et al., 2018). The other trials did not show a beneficial effect: $29 \%$ did not show a statistical difference, and $18 \%$ showed a negative effect. The trials that supplemented arginine in the first third of pregnancy obtained an increase of $10 \%$ in foetal or live weight and an additional 2.2 foetuses or live piglets. The trials that supplemented arginine during the $2^{\text {nd }}$ and $3^{\text {rd }}$ periods of gestation had an average increase of $12 \%$ in the foetal or live piglet weight and an increase in one foetus or live piglet per litter Palencia et al., 2018). Palencia et al. (2018) concluded that supplementing dietary arginine in gestating sows can benefit embryo survival and foetal development. Wu et al. (2018) also reviewed the effect of arginine supplementation in gestating sows. They as well concluded that arginine supplementation in general increases placental weight, the number of live-born piglets per litter and litter birth weights of liveborn piglets. Wu et al. (2018) also reviewed the effect of arginine supplementation in lactating sows. The provision of arginine increases the production of both nitric oxide and polyamines in mammary tissue, and, therefore, it promotes milk production (O'Quinn et al., 2002; Kim and Wu, 2009).

Supplementing $1.0 \%$ arginine to the lactation diet of primiparous sows increased concentration of total amino acids in milk and enhanced litter weight gain by $21 \%$ in the first week of lactation and by $11 \%$ during a 21-d suckling period and (Mateo et al., 2008). Arginine supplementation appears to enhance the efficiency of dietary protein utilization for milk protein synthesis (Mateo et al., 2008). Wu (2014) 
recommends a content of arginine in diets for lactating sows of $1.37 \%$. We do not include arginine in our recommendations because we based our recommendations on a factorial approach. For arginine there is too less information to include this amino acid in a factorial approach. Nonetheless, the results of Palencia et al (2018) and Wu et al. (2018) suggest that arginine supplementation may have beneficial effects on the reproductive performance and milk production of sows. 


\section{References}

ARC. 1967. The nutrient requirements of pigs. Slough, England: Commonwealth Agricultural Bureaux.

Ball, R.O., R.S. Samuel and S. Moehn. 2008. Nutrient Requirements of Prolific Sows. Advances in Pork Production, 19, 223-236.

Beyer, M.. 1986. Untersuchungen zum Energie- und Stoffumsatz von graviden und laktierenden Sauen sowie Saugferkeinn - ein Beitrag zur Präzisierung des Energie- und Proteinbedarfs. Dissertation, Rostock.

Bikker, P. and M.C. Blok. 2017. Phosphorus and calcium requirements of growing pigs and sows. CVB Documentation Report nr. 59.

Bikker, P., J. van Baal and A. Liesegang. 2018. Early nutritional programming of phosphorus metabolism in pigs. Report 1091, Wageningen Livestock Research, Wageningen.

Campbell, R.G. and A.C. Dunkin. 1983. The effects of energy intake and dietary protein on nitrogen retention, growth performance, body composition and some aspects of energy metabolism in baby pigs. British Journal of Nutrition, 49, 221-230.

CVB. 2016. Tabellenboek Veevoeding 2016. Voedernormen varkens en voederwaarden voedermiddelen voor varkens. CVB-reeks nr. 53. Federatie Nederlandse Diervoederketen.

CVB. 2018. CVB Veevoedertabel 2018. Chemische samenstellingen en nutritionele waarden van voedermiddelen. Federatie Nederlandse Diervoederketen.

Darragh, A.J. and P.J. Moughan. 1998. The composition of colostrum and milk. Pp 3-21 in "The lactating sow", Eds. M.W.A. Verstegen, P.J. Moughan and J.W. Schrama, Wageningen Pers, Wageningen.

Devillers, N., J. Le Dividich and A. Prunier. 2011. Influence of colostrum intake on piglet survival and immunity. Animal, 5:10, 1605-1612.

Dourmad, J.Y. and M. Étienne. 2002. Dietary lysine and threonine requirements of the pregnant sow estimated by nitrogen balance. Journal of Animal Science, 80, 2144-2150.

Dourmad, J. Y., M. Etienne, and J. Noblet. 1996. Reconstitution of Body Reserves in Multiparous Sows During Pregnancy: Effect of Energy Intake During Pregnancy and Mobilization During the Previous Lactation. Journal of Animal Science, 74, 2211-2219.

Dourmad, J.Y., M. Etienne, J. Noblet, and D. Causeur 1997. Prédiction de la composition chimique de la truie reproductrice à partir du poids vif et de l'épaisseur de lard dorsal. Journées Rech. Porcine en France, 29, 255-262.

Dourmad, J.Y., J. Noblet, M.C. Père and M. Etienne. 1999. Mating, pregnancy and pre-natal growth. In: Kyriazakis, I. (Ed.), A Quantitative Biology of the Pig. CAB, 129-153.

Dourmad, J.Y., M. Étienne, A. Valancogne, S. Dubois, J. van Milgen and J. Noblet. 2008. InraPorc: A model and decision support tool for the nutrition of sows. Animal Feed Science and Technology, $143,372-386$.

Dourmad, J.Y., P. Gagnon, L. Brossard, C. Pomar and L. Cloutier. 2018. Développement d'un outil d'aide à la décision pour l'alimentation de précision des truies en gestation. Journées Recherche Porcine, 50, 101-106.

Everts, H., M.C. Blok, B. Kemp, C.M.C. van der Peet-Schwering and C.H.M. Smits. 1994. Normen voor dragende zeugen. CVB documentatierappport nr. 9 [in Dutch].

Everts, H., M.C. Blok, B. Kemp, C.M.C. van der Peet-Schwering and C.H.M. Smits. 1995. Normen voor lacterende zeugen. CVB documentatierappport nr. 13 [in Dutch].

Everts, H. and R.A. Dekker. 1994a. Balance trials and comparative slaughtering in breeding sows: Description of techniques and observed accuracy. Livestock Production Science, 37, 339-352.

Everts, H. and R.A. Dekker. 1994b. Effect of nitrogen supply on nitrogen and energy metabolism in lactating sows. Animal Production, 59, 445-454.

Everts, H. and R.A. Dekker. 1995a. Effect of protein supply during pregnancy on body composition of gilts and their products of conception. Livestock Production Science, 43, 27-36.

Everts, H. and R.A. Dekker. 1995b. Effect of protein supply during pregnancy and lactation on body composition of sows during three reproductive cycles. Livestock Production Science, 43, 137-147. 
Feyera, T. and P.K. Theil. 2017. Energy and lysine requirements and balances of sows during transition and lactation: A factorial approach. Livestock Science, 201, 50-57.

Franco, D. J., J.K. Josephson, S. Moehn, P B. Pencharz, and R.O. Ball. 2013. Isoleucine requirement of pregnant sows. Journal of Animal Science, 91, 3859-3866.

Gauthier, R., C. Largouët, C. Gaillard, L. Cloutier, F. Guay and J.Y. Dourmad. 2019. Dynamic modelling of nutrient use and individual requirements of lactating sows. Journal of Animal Science, 97, 2886-2900.

Gill, B.P. 2006. Body composition of breeding gilts in response to dietary protein and energy balance from thirty kilograms of body weight to completion of first parity. Journal of Animal Science, 84, 1926-1934.

Greiner, L., A. Graham, M. Goncalves, U. Orlando, and K.J. Touchette. 2019. Evaluation of the optimal standardized ileal digestible threonine:lysine ratio in lactating sow diets. Journal of Animal Science, 97, 2972-2978.

Hansen, A.V., A.B. Strathe, E. Kebreab, J. France, and P.K. Theil. 2012. Predicting milk yield and composition in lactating sows: A Bayesian approach. Journal of Animal Science, 90, 2285-2298.

Hansen, A.V., A.B. Strathe, P.K. Theil, and E. Kebreab. 2014. Energy and nutrient deposition and excretion in the reproducing sow: Model development and evaluation. Journal of Animal Science, $92,2458-2472$.

Hoving, L. L., N.M. Soede, C.M.C. van der Peet-Schwering, E.A.M. Graat, H. Feitsma, and B. Kemp. 2011. An increased feed intake during early pregnancy improves sow body weight recovery and increases litter size in young sows. Journal of Animal Science, 89, 3542-3550.

Huber, L., M. Rudar, N.L. Trottier, J.P. Cant, and C.F.M. de Lange. 2018. Whole-body nitrogen utilization and tissue protein and casein synthesis in lactating primiparous sows fed low- and highprotein diets. Journal of Animal Science, 96, 2380-2391.

Hughes, P.E., R.J. Smits, Y. Xie, and R.N. Kirkwood. 2010. Relationships among gilt and sow live weight, P2 backfat depth, and culling rates. Journal of Swine Health and Production, 18, 301-305.

Hurley, W.L. 2015. Composition of sow colostrum and milk. Pp 193-229. In "The gestating and lactating sow", ed. C. Farmer, Wageningen Academic Publishers, Wageningen.

Ji, F., G. Wu, J. R. Blanton, and S. W. Kim. 2005. Changes in weight and composition in various tissues of pregnant gilts and their nutritional implications. Journal of Animal Science, 83, 366-375.

Ji, F., W. L. Hurley, and S. W. Kim. 2006. Characterization of mammary gland development in pregnant gilts. Journal of Animal Science, 84, 579-587.

Klaver, J., G.J.M. Van Kempen, P.G.B. De Lange, M.W.A. Verstegen, and H. Boer. 1981. Milk composition and daily yield of different milk components as affected by sow condition and lactation/feeding regimen. Journal of Animal Science, 52, 1091-1097.

Kim, S.W., and G. Wu. 2009. Regulatory role for amino acids in mammary gland growth and milk synthesis. Amino Acids, 37, 89-95.

Kim, S.W., D.H. Baker, and R.A. Easter. 2001. Dynamic ideal protein and limiting amino acids for lactating sows: The impact of amino acid mobilization. Journal of Animal Science, 79, 2356-2366.

Kim, S.W., W.L. Hurley, G. Wu, and F. Ji. 2009. Ideal amino acid balance for sows during gestation and lactation. Journal of Animal Science, 87, E123-E132.

Knauer, M., K.J. Stalder, T. Serenius, T.J. Baas, P.J. Berger, L. Karriker, R.N. Goodwin, R.K. Johnson, J.W. Mabry, R.K. Miller, O.W. Robison, and M.D. Tokach. 2010. Factors associated with sow stayability in 6 genotypes. Journal of Animal Science, 88, 3486-3492.

Koketsu, Y., G.D. Dial, J.E. Pettigrew, and W.E. Marsh. 1996. Characterization of feed intake patterns during lactation in commercial swine herds. Journal of Animal Science 74, 1202-1210.

Leenhouwers, J.I., E.F. Knol, P.N. de Groot, H. Vos, and T. van der Lende. 2002. Fetal development in the pig in relation to genetic merit for piglet survival. Journal of Animal Science, 80, 1759-1770.

Mateo, R.D., G. Wu, H.K. Moon, J.A. Carroll, and S.W. Kim. 2008. Effects of dietary arginine supplementation during gestation and lactation on the performance of lactating primiparous sows and nursing piglets. Journal of Animal Science, 86, 827-835.

McPherson, R.L., F. Ji, G. Wu, J.R. Blanton, Jr., and S.W. Kim. 2004. Growth and compositional changes of fetal tissues in pigs. Journal of Animal Science, 82, 2534-2540

Miller, E.G. 2017. Nitrogen Retention for Maternal and Fetal Tissues in the Gestating Sow. PhD Thesis University of Guelph, Ontario, Canada.

Miller, E.G., C.L. Levesque, N.L. Trottier, and C.F.M. de Lange. 2016. Dynamics of nitrogen retention in gestating gilts at two feeding levels. Journal of Animal Science, 94:3353-3361. 
Miller, E.G., C.L. Levesque, N.L. Trottier, and C.F.M. de Lange. 2017. Dynamics of nitrogen retention at two feeding levels in gestating parity 2 and 3 sows. Journal of Animal Science, 95, 2701-2710.

Mullan, B.P., W.H. Close and D.J.A. Cole. 1993. Predicting nutrient responses of the lactating sow. In: Recent development in pig nutrition 2. Ed. D.J.A. Cole, W. Haresign and P.C. Garnsworthy. Nottingham Press, 332-346.

Moughan, P.J. 1999. Protein metabolism in the growing pig. Pp. 299-331 in Quantitative Biology of the Pig. I. Kyriazakis, ed. Wallingford, UK, CABI.

Noblet, J., W.H. Close, R.P. Heavens and D. Brown. 1985. Studies on the energy metabolism of the pregnant sow. 1. Uterus and mammary tissue development. British Journal of Nutrition, 53, 251265.

Noblet, J., and M. Etienne. 1987. Metabolic utilization of energy and maintenance requirements in lactating sows. Journal of Animal Science, 64, 774-781.

Noblet, J., J. Y. Dourmad and M. Etienne. 1990. Energy utilization in pregnant and lactating sows: modelling of energy requirements. Journal of Animal Science, 68, 562-572.

NRC. 2012. Nutrient requirements of swine. 11th revised edition. National Academic Press, Washington, DC.

O'Quinn, P.R., D.A. Knabe, and G. Wu. 2002. Arginine catabolism in lactating porcine mammary tissue. Journal of Animal Science, 80, 467-474.

Palencia, J.Y.P., M A.G. Lemes, C.A.P. Garbossa, M.L.T. Abreu, L.J. Pereira, M.G. Zangeronimo. Arginine for gestating sows and foetal development: A systematic review. Journal of Animal Physiology and Animal Nutrition, 102, 204-213.

Pluske, J.R. and G.Z. Dong. 1998. Factors influencing the utilisation of colostrum and milk. In: The lactating sow. Ed. M.W.A. Verstegen, P.J. Moughan and J.W. Schrama, 45-70.

RVO. 2019. Mestbeleid 2019-2021. Forfaitaire gehalten stikstof en fosfaat in dieren 2019-2021.

Stein, H.H., N.L. Trottier, C. Bellaver, and R.A. Easter. 1999. The Effect of Feeding Level and Physiological Status on Total Flow and Amino Acid Composition of Endogenous Protein at the Distal Ileum in Swine. Journal of Animal Science, 77:1180-1187.

Strathe, A.V., A.B. Strathe, P.K. Theil, C.F. Hansen and E. Kebreab. 2015. Determination of protein and amino acid requirements of lactating sows using a population-based factorial approach. Animal, 9:8, 1319-1328.

Strathe, A.V., T.S. Bruun, J.-E. Zerrahn, A.-H. Tauson, and C.F. Hansen. 2016. The effect of increasing the dietary valine-to-lysine ratio on sow metabolism, milk production, and litter growth. Journal of Animal Science, 94, 155-164.

Theil, P.K., H. Jørgensen, and K. Jakobsen. 2002a. Energy and protein metabolism in pregnant sows fed two levels of dietary protein. Journal of Animal Physiology and Animal Nutrition, 86, 399-413.

Theil, P.K., T.T. Nielsen, N.B. Kristensen, R. Labouriau, V. Danielsen, C. Lauridsen, and K. Jakobsen. 2002b. Estimation of Milk Production in Lactating Sows by Determination of Deuterated Water Turnover in Three Piglets per Litter. Acta Agriculture Scandinavia, Section A, Animal Science, 52 , 221-232.

Theil, P.K., H. Jørgensen, and K. Jakobsen. 2004. Energy and protein metabolism in lactating sows fed two levels of dietary fat. Livestock Production Science, 89, 265-276.

Trottier, N.L., L.J. Johnston and C.F.M. de Lange. 2015. Applied amino acid and energy feeding of sows. Pp 117-145. In "The gestating and lactating sow", ed. C. Farmer, Wageningen Academic Publishers, Wageningen.

Van Milgen, J.M., A. Valancogne, S. Dubois, J.Y. Dourmad, B. Sève and J. Noblet. 2008. InraPorc: A model and decision support tool for the nutrion of growing pigs. Animal Feed Science and Technology, 143, 387-405.

Van Milgen, J.M. and J.Y. Dourmad. 2015. Concept and application of ideal protein for pigs. Journal of Animal Science and Biotechnology 6, 15-25.

Van Rens, B.T.T.M., G. de Koning, R. Bergsma, and T. van der Lende. 2005. Preweaning piglet mortality in relation to placental efficiency. Journal of Animal Science, 83, 144-151.

Wattanakul, W., C.A. Bulman, H.L. Edge, and S.A. Edwards. 2005. The effect of creep feed presentation method on feeding behaviour, intake and performance of suckling piglets. Applied Animal Behaviour Science 92, 27-36.

Werkgroep TMV. 1991. Informatiemodel Technisch Model Varkensvoeding. Proefverslag P1.66, Wageningen University and Research, Wageningen. 
Whittemore, C.T., and C.A. Morgan. 1990. Model components for the determination of energy and protein requirements for breeding sows: a review. Livestock Production Science, 26, 1-37.

Wu, G. 2014. Dietary requirements of synthesizable amino acids by animals: a paradigm shift in protein nutrition. Journal of Animal Science and Biotechnology, 5:34.

Wu, G., T.L. Ott, D.A. Knabe and F.W. Bazer. 1999. Amino Acid Composition of the Fetal Pig. Journal of Nutrition, 129, 1031-1038.

Wu, G., F.W. Bazer, G.A. Johnson, Y. Hou. 2018. Arginine nutrition and metabolism in growing, gestating, and lactating swine. Journal of Animal Science, 96, 5035-5051.

Yoder, C.L., C.R. Schwab, J.S. Fix, K.J. Stalder, P.M. Dixon, V.M. Duttlinger, and T.J.Baas. 2013. Estimation of deviations from predicted lactation feed intake and the effect on reproductive performance. Livestock Science, 154, 184-192. 


\section{Appendix 1 Development in BW and body composition of sows}

\begin{tabular}{|c|c|c|c|c|c|c|}
\hline Parity & 1 & 2 & 3 & 4 & 5 & 6 \\
\hline Litter size, total born & 15 & 16 & 16 & 16 & 16 & 16 \\
\hline Birth weight, kg & 1.25 & 1.40 & 1.40 & 1.40 & 1.40 & 1.40 \\
\hline Weaned piglets & 12 & 13 & 13 & 13 & 13 & 13 \\
\hline \multicolumn{7}{|l|}{ Sow at mating } \\
\hline Body weight, kg & 140 & 165 & 185 & 205 & 220 & 235 \\
\hline P2 backfat, mm & 13 & 12 & 13 & 13 & 13 & 13 \\
\hline Protein mass, kg & 20.9 & 25.6 & 28.6 & 32.0 & 34.6 & 37.2 \\
\hline Lipid mass, kg & 24.4 & 28.1 & 34.0 & 38.2 & 41.4 & 44.6 \\
\hline \multicolumn{7}{|c|}{$\begin{array}{l}\text { Sow at farrowing (excl uterine } \\
\text { contents) }\end{array}$} \\
\hline Body weight, kg & 195 & 215 & 230 & 245 & 255 & 265 \\
\hline $\mathrm{P} 2$ backfat, mm & 17 & 17 & 17 & 17 & 17 & 17 \\
\hline Protein mass, kg & 28.7 & 32.1 & 34.7 & 37.2 & 38.9 & 40.7 \\
\hline Lipid mass, kg & 42.6 & 46.8 & 50.0 & 53.2 & 55.3 & 57.4 \\
\hline \multicolumn{7}{|l|}{ Sow at weaning } \\
\hline Body weight, kg & 172.5 & 192.5 & 212.5 & 227.5 & 242.5 & \\
\hline P2 backfat, mm & 12.75 & 13.75 & 13.75 & 13.75 & 13.75 & \\
\hline Protein mass, kg & 26.6 & 29.6 & 33.0 & 35.6 & 38.1 & \\
\hline Lipid mass, kg & 30.9 & 36.8 & 41.0 & 44.2 & 47.4 & \\
\hline \multicolumn{7}{|l|}{$\begin{array}{l}\text { Retention in gestation (excl } \\
\text { uterine contents) }\end{array}$} \\
\hline Body mass, kg & 55 & 50 & 45 & 40 & 35 & 30 \\
\hline Real body gain, kg & 55 & 20 & 15 & 15 & 10 & 10 \\
\hline Recovery of weight loss, kg & 0 & 30 & 30 & 25 & 25 & 20 \\
\hline Protein, kg & 7.8 & 6.5 & 6.1 & 5.2 & 4.4 & 3.5 \\
\hline Protein in real gain, $\mathrm{kg}$ & 7.8 & 3.4 & 2.6 & 2.6 & 1.7 & 1.7 \\
\hline Recovery of protein loss, $\mathrm{kg}$ & 0.0 & 3.1 & 3.5 & 2.6 & 2.6 & 1.8 \\
\hline Lipid, kg & 18.2 & 18.7 & 16.0 & 15.0 & 13.9 & 12.9 \\
\hline Lipid in real gain, $\mathrm{kg}$ & 18.2 & 4.2 & 3.2 & 3.2 & 2.1 & 2.1 \\
\hline Recovery of lipid loss, kg & 0.0 & 14.5 & 12.9 & 11.8 & 11.8 & 10.7 \\
\hline Recalculated body mass $^{1}, \mathrm{~kg}$ & 52.4 & 47.4 & 42.7 & 37.9 & 33.1 & 28.3 \\
\hline$P D, g / d$ & 68 & 57 & 53 & 45 & 38 & 30 \\
\hline$L D, g / d$ & 158 & 163 & 139 & 130 & 121 & 112 \\
\hline \multicolumn{7}{|l|}{ Mobilisation in lactation } \\
\hline Body mass, kg & 22.5 & 22.5 & 17.5 & 17.5 & 12.5 & \\
\hline Protein, kg & 2.1 & 2.5 & 1.7 & 1.7 & 0.8 & \\
\hline Lipid, kg & 11.7 & 10.1 & 9.0 & 9.0 & 7.9 & \\
\hline \multicolumn{7}{|l|}{ Loss in lactation + interval } \\
\hline Body mass, kg & 30.0 & 30.0 & 25.0 & 25.0 & 20.0 & \\
\hline Protein, kg & 3.1 & 3.5 & 2.6 & 2.6 & 1.8 & \\
\hline Lipid, kg & 14.5 & 12.9 & 11.8 & 11.8 & 10.7 & \\
\hline
\end{tabular}




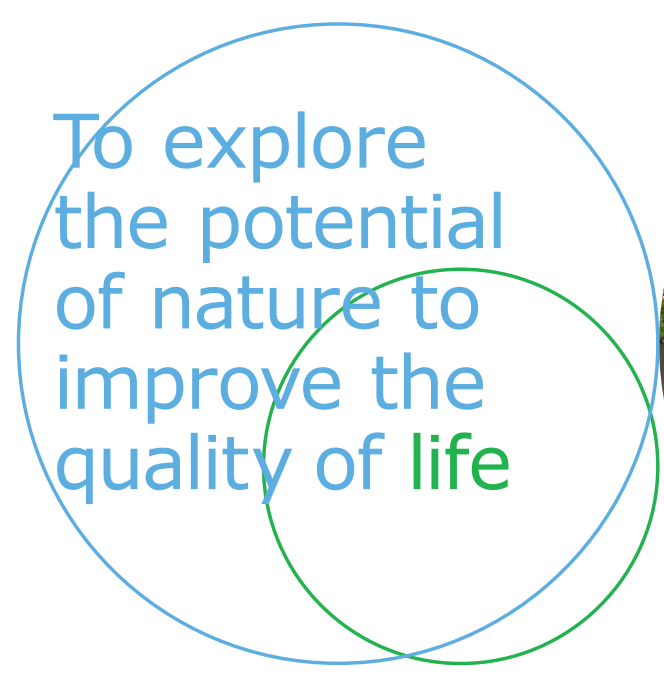

Wageningen Livestock Research P.O. Box 338

$6700 \mathrm{AH}$ Wageningen

The Netherlands

$T+31(0) 317483953$

E info.livestockresearch@wur.nl www.wur.nl/livestock-research

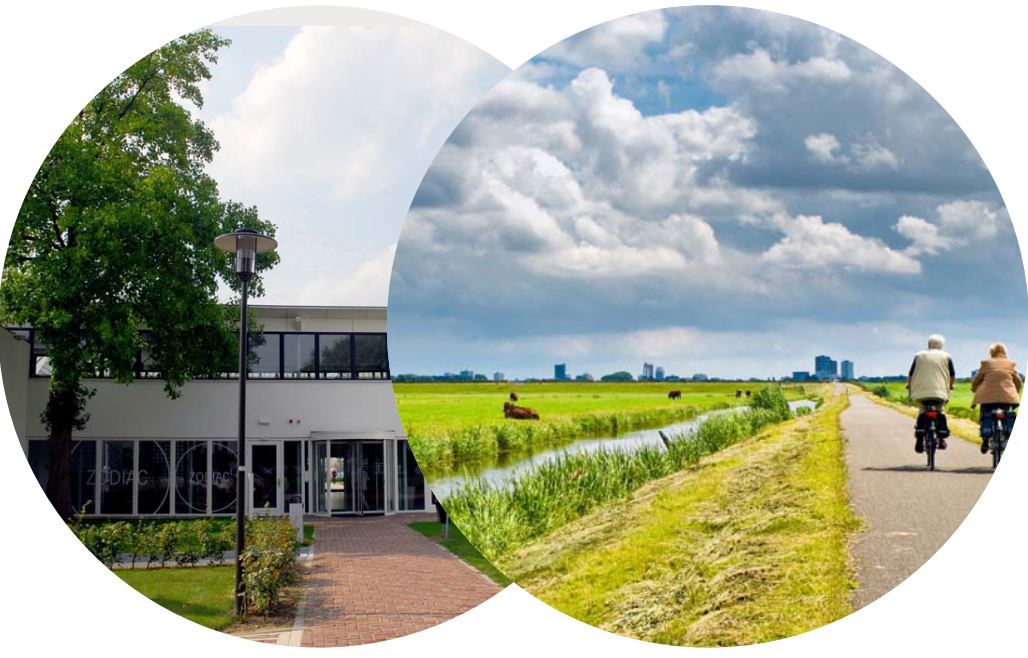

Wageningen Livestock Research creates science based solutions for a sustainable and profitable livestock sector. Together with our clients, we integrate scientific knowledge and practical experience to develop livestock concepts for future generations.

Wageningen Livestock Research is part of Wageningen University \& Research. Together we work on the mission: 'To explore the potential of nature to improve the quality of life'. A staff of 6,500 and 10,000 students from over 100 countries are working worldwide in the domain of healthy food and living environment for governments and the business community-at-large. The strength of Wageningen University \& Research lies in its ability to join the forces of specialised research institutes and the university. It also lies in the combined efforts of the various fields of natural and social sciences. This union of expertise leads to scientific breakthroughs that can quickly be put into practice and be incorporated into education. This is the Wageningen Approach. 